Peer Reviewed Paper openaccess Special Issue on Spectral Imaging in Synchrotron Light Facilities

\title{
Physicochemistry in medicine: some selected examples
}

\author{
Dominique Bazin ${ }^{\mathrm{a}, *}$ and Michel Daudon ${ }^{\mathrm{b}, \mathrm{c}}$ \\ aLaboratoire de Chimie Physique, Université Paris Sud, 310 Rue Michel Magat, 91400 Orsay, France. E-mail: dominique.bazin@u-psud.fr, \\ (1) https://orcid.org/0000-0002-5112-9061 \\ bInserm, UMRS 1155, UPMC, Hôpital Tenon, 75970 Paris, France. 이 https://orcid.org/0000-0001-9844-9823 \\ 'Service d'explorations fonctionnelles, Hôpital Tenon, AP-HP, 4, rue de la Chine, 75970 Paris cedex 20, France
}

\begin{abstract}
Research on pathological calcifications constitutes an exciting topic at the interface between physics, chemistry and medicine. The relationship between their physicochemical characteristics and the pathology responsible for their formation offers a unique opportunity to perform a significant medical diagnosis, to assess the interaction between drugs and these biological entities as well as to develop new drugs. Regarding synchrotron radiation, the emergence of microbeam allows the clinician to perform an early diagnosis. Indeed, we will start this review with a clinical case where Fourier transform infrared spectroscopy using synchrotron radiation as a probe allowed the clinician to save the kidney function of a patient. Following this example, we will see that investigations on pathological calcifications constitute an elegant way to gather major information on different public health problems such type 2 diabetes as well as on rare diseases. To attain this goal, this mini-review dedicated to structural and chemical investigations and based on selected and recent data collected through techniques using third generation synchrotron radiation as a probe is proposed to the reader.
\end{abstract}

Keywords: physicochemistry, medicine, pathological calcifications, lithiasis, kidney stones, Randall's plaque, synchrotron, infrared spectroscopy, UV-visible spectroscopy, X-ray fluorescence, X-ray absorption

\section{Introduction}

Pathological calcification (PC) occurs frequently in medicine. ${ }^{1-4}$ A large part of the literature has tried to demonstrate a causal relationship between PC and pathology. Also, it is worth underlining that controversies exist regarding this link. A wellestablished relation between calciphylaxis (calcium deposits in the vascular walls) and deleterious consequences such as an increased mortality in affected patients) has been reported in patients suffering end stage renal failure. ${ }^{5}$ Gout cases related to the crystallisation of sodium hydrogen urate in synovial fluid are well documented. ${ }^{6}$ Renal failure due to crystalline deposits within the kidney was reported in a variety of diseases resulting in the crystallisation of poorly soluble substances excreted by the kidney. Regarding prostate tissue, it is common to find calcium deposits without any obvious relation to the pathology (prostate hypertrophy, adenoma or
Correspondence

D. Bazin (dominique.bazin@u-psud.fr)

Received: 5 April 2019

Revised: 28 July 2019

Accepted: 30 August 2019

Publication: 5 September 2019

doi: 10.1255/jsi.2019.a16

ISSN: $2040-4565$

\section{Citation \\ D. Bazin and M. Daudon, "Physicochemistry in medicine: some selected examples", J. Spectral Imaging 8, a16 (2019). https://doi.org/10.1255/jsi.2019.a16 \\ (C) 2019 The Authors}

This licence permits you to use, share, copy and redistribute the paper in any medium or any format provided that a full citation to the original paper in this journal is given, the use is not for commercial purposes and the paper is not changed in any way. 
cancer)..$^{7,8}$ Note that the link between calcification and pathology could be the crystalline species identified within the tissue. For example, breast tumours may be associated with weddellite crystals or with calcium phosphate deposits. It was reported that tumours are benign in the case of calcium oxalate and benign or malignant in the case of calcium phosphate. ${ }^{9-11}$

In the medical literature, papers consider that PCs are made mainly of calcium and distinguish two forms of PC. This dystrophic one occurs in dying and dead tissue. It is well known that injured and dying cells are not able to maintain normal calcium homeostasis, leading to an increase of intracellular calcium levels. The second family, the metastatic calcifications, are associated with elevated extracellular levels of calcium (hypercalcemia), exceeding the homeostatic capacity of cells and tissues. These two definitions are based on the metabolism of calcium. Unfortunately, more than 100 chemical phases have been identified in PC and most of them do not contain calcium. ${ }^{2,4}$ Such experimental facts call for another classification based on their pathogenesis process.

We have proposed a more general classification for PC made of three families. ${ }^{1-4}$ First, concretions which are found in hollow organs or ducts of the body. For example, kidney stones are solid concretions of dissolved minerals in urine. ${ }^{12-15}$ In the case of concretions, crystallisation is induced in metastable supersaturated solutions by spontaneous nucleation when a certain degree of supersaturation is reached (homogeneous nucleation). In contrast, ectopic calcifications are defined as unexpected biomineralisation occurring in soft tissues. It is worth underlining that metastatic and dystrophic calcifications can be considered ectopic calcifications. We may have PCs related to homogeneous and heterogeneous nucleation. This is the case of kidney stones attached at the surface of Randall's plaque (RP). Crystallites in urine (homogeneous nucleation) are agglomerated at the surface of RP which serves as a nucleus (heterogenous nucleation). ${ }^{16}$ A third family can be related to physiological calcifications (otoliths, tooth, ${ }^{17}$ bone) which becomes pathological with diseases (bone and osteoporosis ${ }^{18,19}$ ).

In fact, several questions should be answered in the case of crystal deposits within a tissue: what is the accurate composition of the crystal? Is the crystal a specific marker for a pathology? What is the interaction between the crystal and the tissue? Physical methods, including ones implemented on synchrotron facilities, may be of a valuable help to answer all these questions (see, for example, Reference 20).

\section{A clinical case based on synchrotron data}

We start this review with the presentation of a clinical case where the characterisation of $\mathrm{PC}^{1-4}$ through $\mu \mathrm{FT}-\mathrm{IR}$ (Fourier transform infrared) spectroscopy performed on the SMIS (Spectroscopy and Microscopy in the Infrared region using Synchrotron) beamline of the SOLEIL (Source Optimisée de Lumière d'Energie Intermédiaire du LURE) Synchrotron plays a pivotal role. A 64-year-old woman was admitted to a nephrology unit for rapidly progressive renal insufficiency with an increased serum creatinine level of about $500 \mathrm{\mu mol} \mathrm{L}^{-1}$ giving an estimated glomerular filtration rate of $10 \mathrm{~mL} \mathrm{~min}^{-1} / 1.73 \mathrm{~m}^{2}$. Such a high value for serum creatinine corresponds to a severe impairment of kidney function (normal value $>90 \mathrm{~mL} \mathrm{~min}^{-1} / 1.73 \mathrm{~m}^{2}$ ). The analysis of her medical file revealed a well-controlled hypertension diagnosed 10 years before as well as a chronic renal failure diagnosed 2 years before with a serum creatinine at $215 \mathrm{mmol} \mathrm{L}^{-1}$. This chronic renal failure was attributed to nephroangiosclerosis, a disease related to hypertension. The fact that this rapidly progressive renal insufficiency failure was not associated to an obvious cause led to a renal biopsy (RB). RB is often necessary for diagnosis, prognostic assessment and therapy guidance of various diseases affecting native and transplanted kidneys. ${ }^{21}$ The final diagnosis differs from the main hypothesis in up to one-third of cases. ${ }^{22}$ The observation through an optical microscope of the RB shows an extensive tubulo-interstitial fibrosis scattered with multiple small crystallites. For this patient, such observation was definitely not able to determine the chemical nature of these small crystallites (Figure 1.A1).

At this point, it is worth emphasising that more than 20 chemical compounds have been identified including 7 different calcium salts. ${ }^{23}$ Thus, the methods used in the hospital setting to gather information on PC in RB are clearly inappropriate. These methods based on staining procedures such as von Kossa staining display some major limitations for the characterisation of ectopic calcifications. It was reported that such staining procedures are not 


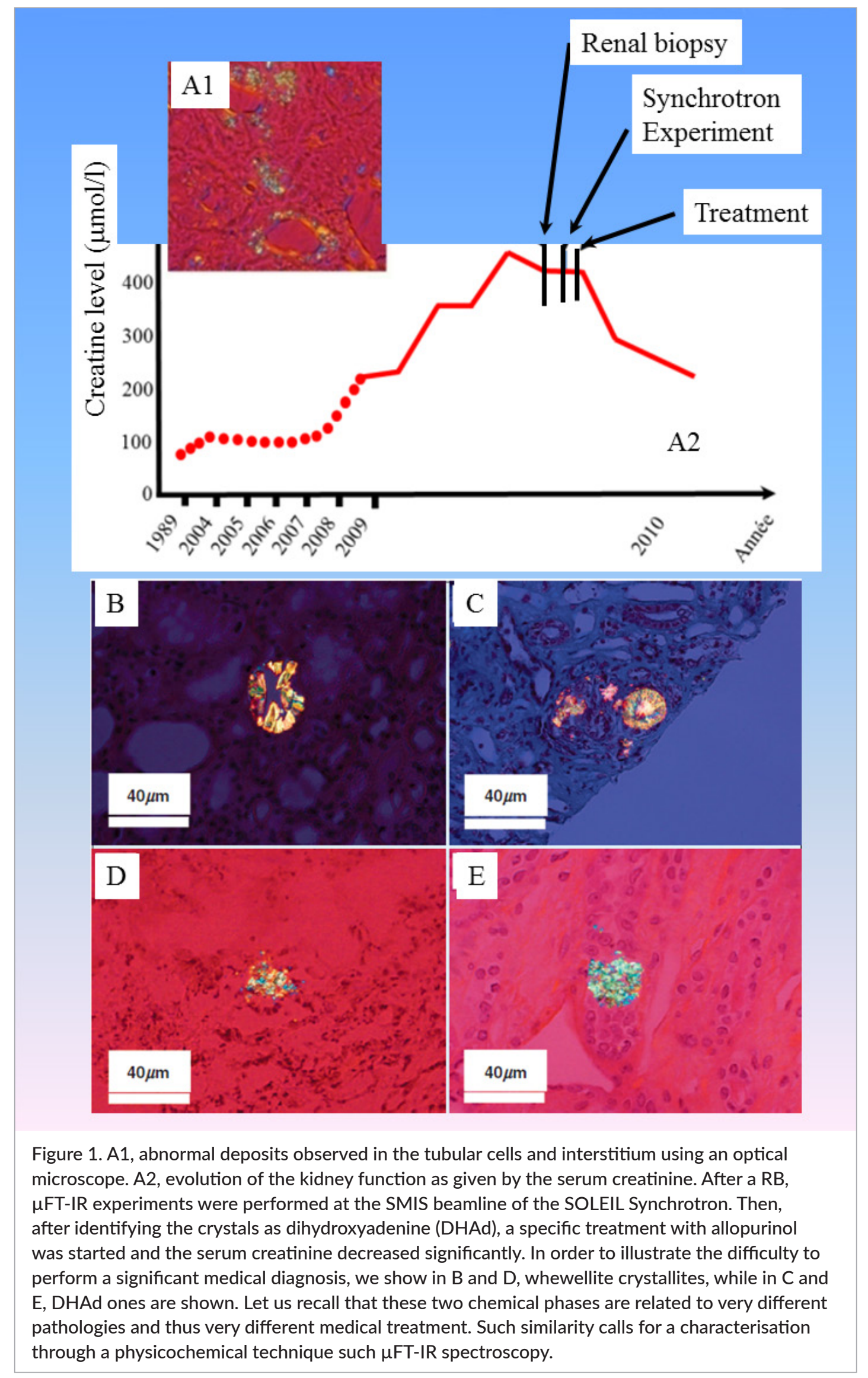


sufficient for identifying and quantifying apatite to assess bone formation. ${ }^{24}$

Regarding the patient, a genetic investigation is also an option to perform a significant diagnosis. Unfortunately, the cost of such investigation is high. Also, it requires quite a long time. Note that such an approach through genetics must be guided by clinical and biological data. Here an accurate characterisation of the crystals found within the tissue gives key information to the clinician. To identify the chemical nature of the small crystallites, we selected $\mu$ FT-IR spectroscopy and went to the SMIS beamline of the SOLEIL Synchrotron to perform such an experiment. Quickly, the presence of 2,8-dihydroxyadenine (DHAd) was identified in the kidney biopsy. This compound is produced by the body when it is unable to recycle adenine. ${ }^{25}$ This early diagnosis based on synchrotron data made all the difference. The medical treatment (now allopurinol or febuxostat) of the disease thus identified is available and was applied at once. The kidney function of the patient finally recovered. Such diagnosis changed significantly the life of the patient because it was not necessary for her to have dialysis and thus a kidney transplantation. This clinical case has been reported on different websites ${ }^{26}$ and published. ${ }^{27}$

From a financial point of view, the cost of an undiagnosed case leading to end stage renal failure is at least $85 \mathrm{k} €$ per year for dialysis (the average time before kidney transplantation is about 18-24 months), $85 \mathrm{k} €$ for the kidney graft (around 3100 kidney transplantations per year in France), and finally $10 \mathrm{k} €$ per year of medical therapy, management of side effects and follow-up of the patient. By comparison, the cost of $8 \mathrm{~h}$ synchrotron use to establish a clinically relevant diagnosis is $4 \mathrm{k} €$ (half an hour is in fact sufficient) while the price of a last generation in-lab $\mu F T-I R$ spectrometer is around $300 \mathrm{k} €$ and the cost of an analysis on this equipment is around $160 €$. In conclusion, the patient saves her kidney and social security saves some money (more than $350 \mathrm{k} €$ ). ${ }^{28}$

Thanks to different state agencies, two in-lab $\mu F T-I R$ spectrometers allowing us to perform experiments very similar to the one performed on SMIS have been installed at the physiology unit of Tenon Hospital. This clinic case was thus the starting point of a large survey on grafted patients (more than 300 patients are engaged in this investigation) in collaboration with Huriez Hospital, Lille, France. The first patient for which the $\mu$ FT-IR measurement was performed at Tenon Hospital was a four-year old girl already transplanted and who presented with a kidney graft dysfunction. She had DHAd crystallites present in the RB. Thanks to an early diagnosis of the crystals using $\mu F T-I R$ spectroscopy, she received allopurinol and she recovered her kidney graft function. At this point, it is worth underlining that since the installation of this apparatus at the Tenon Hospital, 18 patients have been diagnosed with the same pathology.

This preamble shows clearly that PC constitutes an exciting entry point for physicists and chemists in medical research. Regarding the interface between physics and medicine, let us note that the first medical application of X-rays was made by W.C. Röntgen in 1895 through an image of a left hand; this image was in fact the discovery of X-rays. Now, part of the cutting-edge research done in medicine is performed on numerous beamlines implemented on several synchrotron radiation centres. $^{29-31}$ At SOLEIL, the French synchrotron facility, the first experiment was performed on kidney stones. ${ }^{32}$ Note that a beamline of the European Synchrotron Radiation Facility (ESRF) is dedicated to research in medicine. ${ }^{33-35}$

One of the key points of the research dedicated to $P C$ is linked to the relationship between the pathology which induces such biological entities and their physicochemical characteristics. ${ }^{12,13,36-38}$ Such a relationship allows the clinician to establish an early diagnosis and also to develop new drugs. ${ }^{39}$ In this review, we would like to present some recent publications related essentially to $P C$ which illustrate the interest of the medical community in synchrotron radiation. To attain this goal, we will start with some generalities regarding PC. ${ }^{40,41}$ Then we will present succinctly different techniques, namely $X$-ray fluorescence, ${ }^{42}$ scattering techniques, ${ }^{43} \mathrm{X}$-ray absorption spectroscopy, ${ }^{44,45}$ FT-IR spectroscopy ${ }^{46,47}$ and UV-visible spectroscopy. ${ }^{48,49}$ For each characterisation tool, some examples will be given.

\section{Some generalities of PCs Ubiquity of the PC}

PC may occur in various parts of the body, namely kidneys, ${ }^{12-16}$ arteries, $^{50,51}$ breast, ${ }^{52-54}$ gallbladder, ${ }^{55,56}$ liver, ${ }^{57}$ pancreas, ${ }^{58,59}$ prostate, ${ }^{60,61}$ saliva, ${ }^{62}$ thyroid, ${ }^{63}$ heart ${ }^{64}$ and cartilage. ${ }^{65-68}$ Calcifications may occur also 


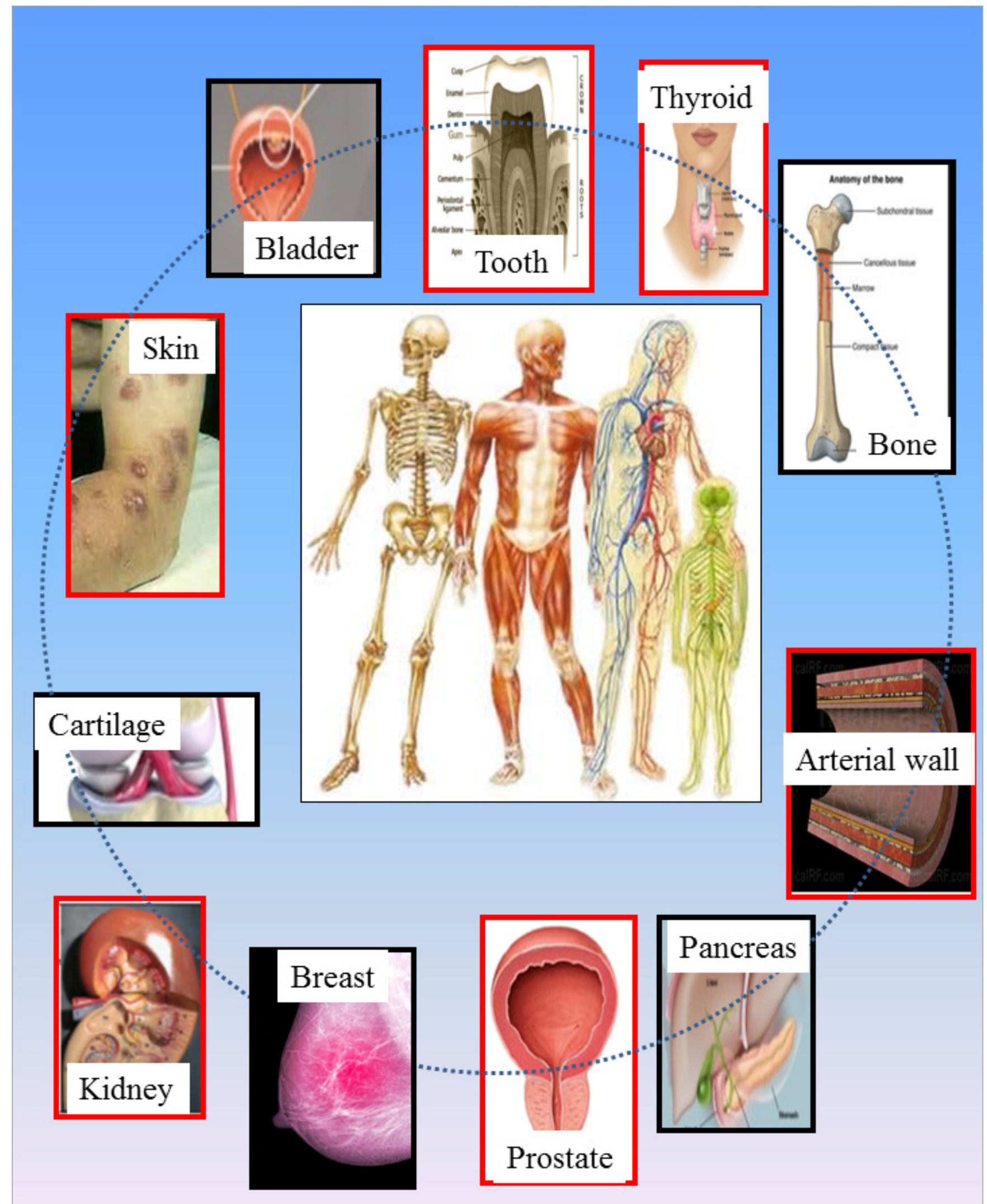

Figure 2. Ubiquity of PC. This figure shows the different locations for the $\mathrm{PC}$ we have selected in our research. 
on medical devices namely bioprosthetic heart valves, ${ }^{69}$ mammary implants, ${ }^{70}$ stents $^{71,72}$ and intraocular lens. ${ }^{73}$ In Figure 2, we present the different organs we have selected for our research on PC. Such approach allows us to assess the different models proposed by the clinician for the pathogenesis of the PC.

For example, in a translational investigation dedicated to the calcifications present in the vessel wall, the data suggest that free DNA coming from cell lysis could be involved in the very first steps of the pathogenesis of these biological entities. ${ }^{50}$ The formation of kidney stones is principally related to supersaturation. ${ }^{12,13}$ Such considerations demonstrate clearly that only a strong relationship between physico-chemist and physicists may lead to significant breakthroughs.

Finally, such set of samples allows us to consider different types of pathologies and in Figure 3 we show different images obtained on a scanning electron microscope corresponding to kidney infection, ${ }^{74}$ breast cancer, ${ }^{75}$ iatrogenic $^{76}$ and genetic diseases. ${ }^{77,78}$

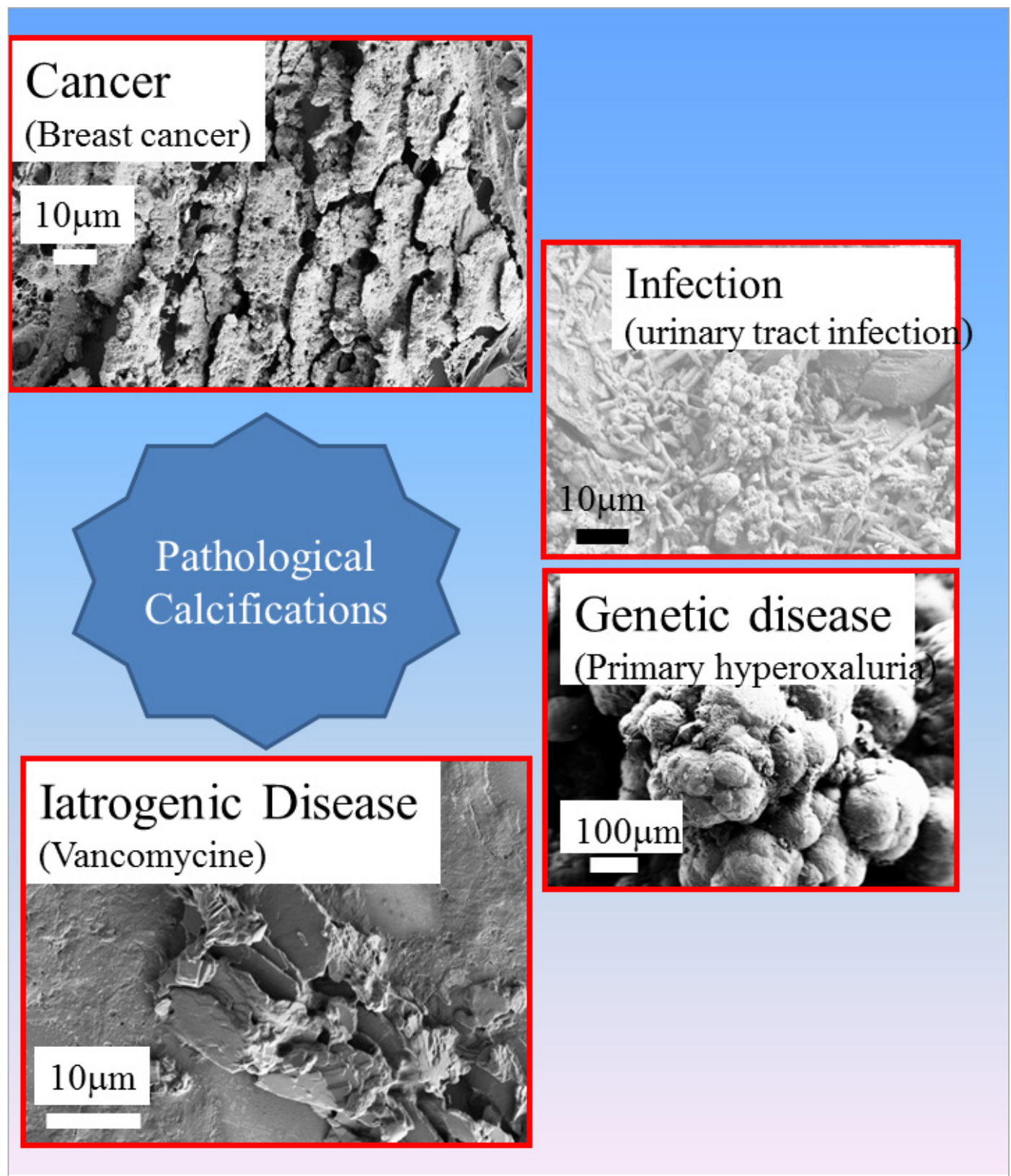

Figure 3. PC are observed for very different pathologies encompassing cancer, infection, genetic disorders and iatrogenic diseases. 


\section{A huge chemical diversity}

Various medical papers and presentations assume that $\mathrm{PC}$ is a lesion in which calcium salts, usually in the form of calcium phosphate with an apatite structure, are deposited abnormally in soft tissues. ${ }^{79}$ The analysis of the literature shows that this point does not take into account the huge chemical diversity of these biological entities. Uric acid ${ }^{80}$ as well as amino acids such as cystine $81-84$ have been identified in PC. Such biological entities may also have an exogenous origin. For example, in kidney, drug-induced renal calculi have been identified ${ }^{76}$ and drug crystals in tubules of the kidney have been identified as the cause of kidney injury. ${ }^{85,86}$ Other drug crystals responsible for tissue lesions have been reported in the gut. ${ }^{87}$ Finally, some silica objects have been identified in the centre of granuloma present in skin and also in kidney stones. ${ }^{88-91}$ In a recent publication, following a demand from a dermatologist, we analysed abnormal deposits present on the surface of hairs. We pointed out the presence of titanium dioxide. ${ }^{92}$

\section{Characterisation of PCs}

\section{From micrometre scale to nanometre scale}

The starting point of this research dedicated to PC has been performed essentially at the micrometre scale using mainly in-lab characterisation techniques. ${ }^{93,94}$ More precisely, two characterisation tools have been used namely field emission scanning electron microscopy $^{23}$ and $\mu$ FT-IR spectroscopy. ${ }^{93}$ The definition of such approach was made on the basis of the morphoconstitutional model. ${ }^{12}$ Then, we begin a physicochemical description at the nanometre scale based on different techniques using synchrotron radiation as a probe. ${ }^{95}$ At the nanoscale, major information can be obtained on the pathogenesis of kidney stones. ${ }^{96,97}$ In our case, we have used several experimental setups to characterise or mimic the pathogenesis process. ${ }^{98,99}$ Among them, let us highlight transmission electron microscopy ${ }^{97}$ and nuclear magnetic resonance ${ }^{100}$ (Figure 4).

As can be seen in Figure 5, such approach has been used to study Wilson's disease (WD), theranostic vectors, as well as for the interaction between tea and kidney stones. For example, we have proposed an $X$-ray fluorescence (XRF) spectroscopy-based approach on liver tissue as a diagnostic tool for WD, also known as hepatolenticular degeneration, which is a severe disorder of copper homeostasis caused by mutations in the gene ATP7B encoding a copper-transporting P-type ATPase. ${ }^{101}$ Also, a new rapid scan method, Flyscan mode, implemented on the DiffAbs beamline ${ }^{102}$ at SOLEIL Synchrotron which allows fast $\mu \mathrm{XRF}$ data acquisition has been used to gather a complete set of data acquired after injection of gold-cluster-enriched mesoporous silica nanospheres, used as potential theranostic vectors, into rats. ${ }^{103}$ Finally, we have recently performed a study to assess the possible interaction between green tea, which is widely used as a "healthy" beverage due to its high level of antioxidant polyphenol compounds, and kidney stones made of calcium oxalate. Our data show no evidence for increased stone risk factors or oxalate-dependent stones in daily green tea drinkers. ${ }^{104}$

\section{Fourier transform infrared spectroscopy}

FT-IR spectroscopy has been proved to be a powerful characterisation tool for investigations on inorganic as well as organic chemical compounds in both qualitative and quantitative modes. ${ }^{46,47}$ This technique is nondestructive and label-free. FT-IR spectroscopy probes vibrational energy levels providing chemical as well as structural information by comparison with database reference spectra. ${ }^{105-107}$ The formalism associated with classical $\mu F T-I R$ spectroscopy indicates that the spatial resolution is limited by the diffraction, its value being around $5 \mu \mathrm{m}$. Recently, FT-IR spectroscopy has been combined with atomic force microscopy to break through the diffraction limit leading to a spatial resolution of 20-40 nm. ${ }^{108,109}$

Nowadays, FT-IR spectroscopy is routinely used at several hospitals. Among these, we can cite the characterisation of lipids in graft liver at the Paul Brousse hospital, ${ }^{110}$ of concretions and ectopic calcifications in kidney biopsies for 30 years at the Necker hospital and subsequently at the Tenon Hospital. ${ }^{111,112}$ Thanks to the morphoconstitutional model, ${ }^{12}$ which is a significant relationship between the physicochemical characteristics of urinary stones and the pathology which induces the formation of these biological entities, different epidemiologic breakthroughs have been made.

For example, a specific morphology for apatite kidney stones has been observed in $96.1 \%$ of stones associated 


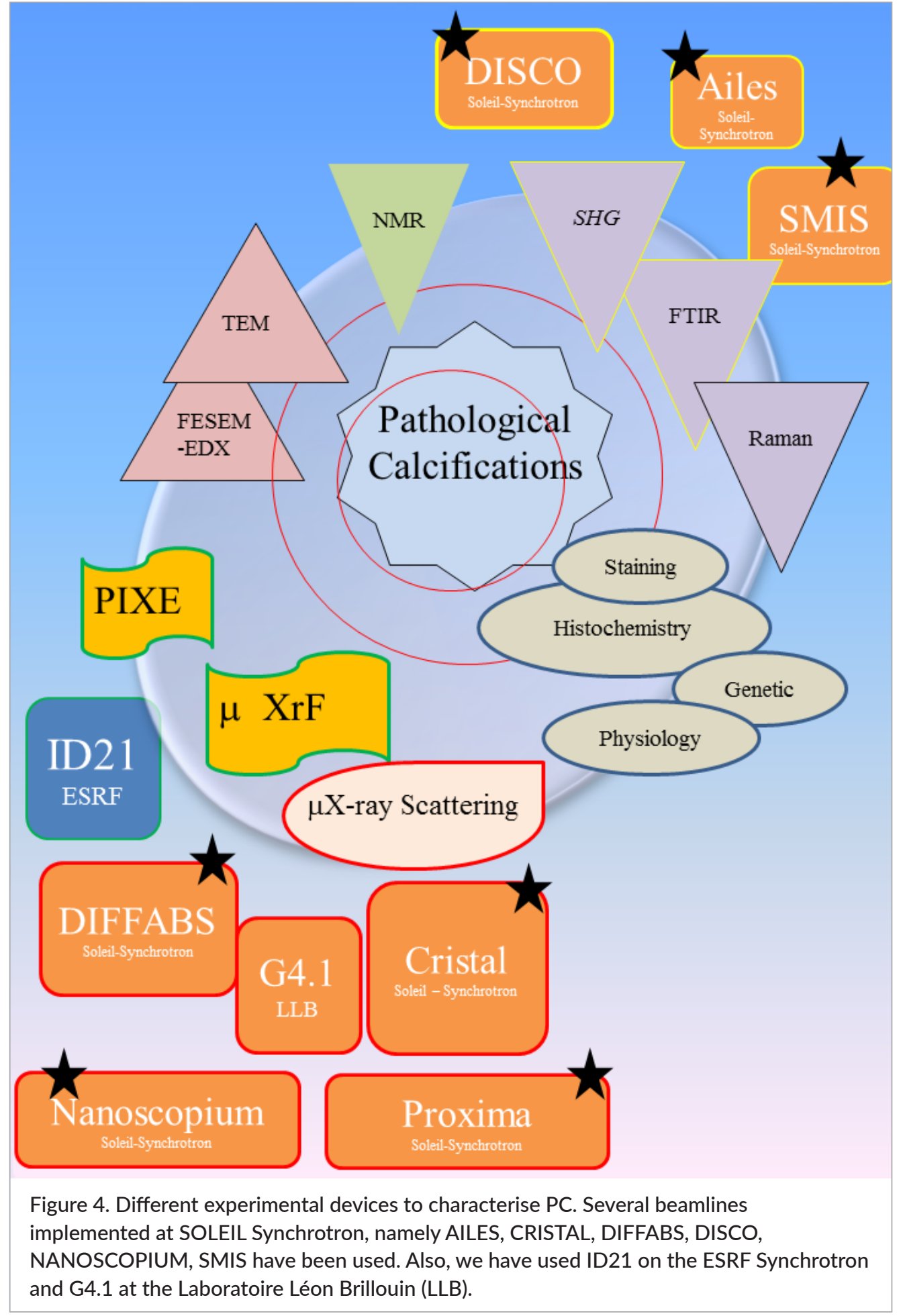

with inherited distal renal tubular acidosis. ${ }^{113}$ In contrast, other stones of similar composition but different morphologies observed through optical microscopy were related to distal renal tubular acidosis in only $3.9 \%$ of cases. Also, the distribution of the main stone components was analysed in a series of 2464 calculi from 272 (11\%) patients with type 2 diabetes and 2192 without type 2 diabetes. The proportion of uric acid stones was $35.7 \%$ in patients with type 2 diabetes and $11.3 \%$ in patients without type 2 diabetes ( $p<0.0001) .{ }^{114}$ Another example is provided by kidney stones related to infection. ${ }^{74}$ FT-IR spectroscopy data have clearly established that 


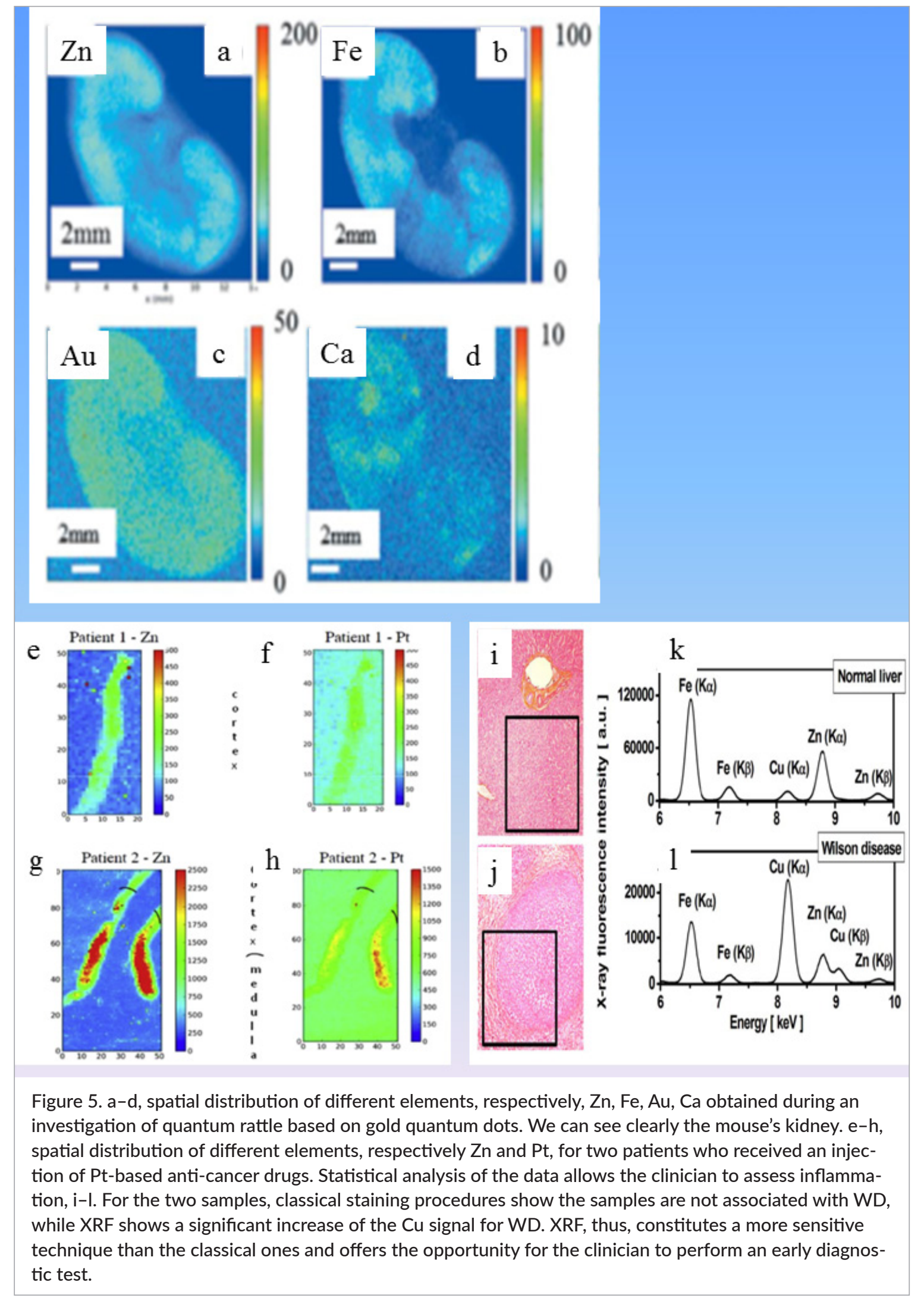


stones resulting from urinary tract infection due to urea-splitting bacteria consist of calcium phosphate hydroxyapatite admixed with struvite and exhibit a high $\mathrm{CO}_{3}^{2-}$ content. ${ }^{115,116}$ Finally, as mentioned previously, several papers show the large chemical diversity of the abnormal deposits in kidney biopsies. ${ }^{117-119}$

In Figure 6, we use the fact that high spatial resolution infrared mapping constitutes a very powerful tool to study the kidney distribution of foscarnet and metabolites. It is well known that foscarnet crystallises in glomeruli. ${ }^{27}$ Foscarnet (phosphonoformic acid) is a pyrophosphate analogue that inhibits the DNA polymerase of all herpes viruses. Foscarnet is commonly used in immuno-suppressed patients (AIDS, grafted patients) who have developed cytomegalovirus infection. Through $\mu F T$-IR performed on the SMIS beamline, we confirmed the presence of sodium foscarnet crystals in glomeruli. In addition, we found in the cells of the proximal tubule a deposit made of calcium phosphate apatite. Such experimental data suggest that the drug is locally metabolised by splitting the bond between the two phosphate residues of foscarnet. To the best of our knowledge, no experimental data has been reported about crystalline or amorphous chemical phases deposited within the cells of the tubules in the kidney.

\section{UV-visible spectroscopy}

We discuss another, recent clinical case already presented at a conference. ${ }^{120}$ A 7-month old child, who did not present any comorbidities, developed an end stage renal failure of unclear origin. The first retained diagnosis was acute tubular necrosis secondary to acute dehydration in a context of sepsis. Renal ultrasound showed two well-differentiated kidneys measuring $57 \mathrm{~mm}$ and $69 \mathrm{~mm}$.

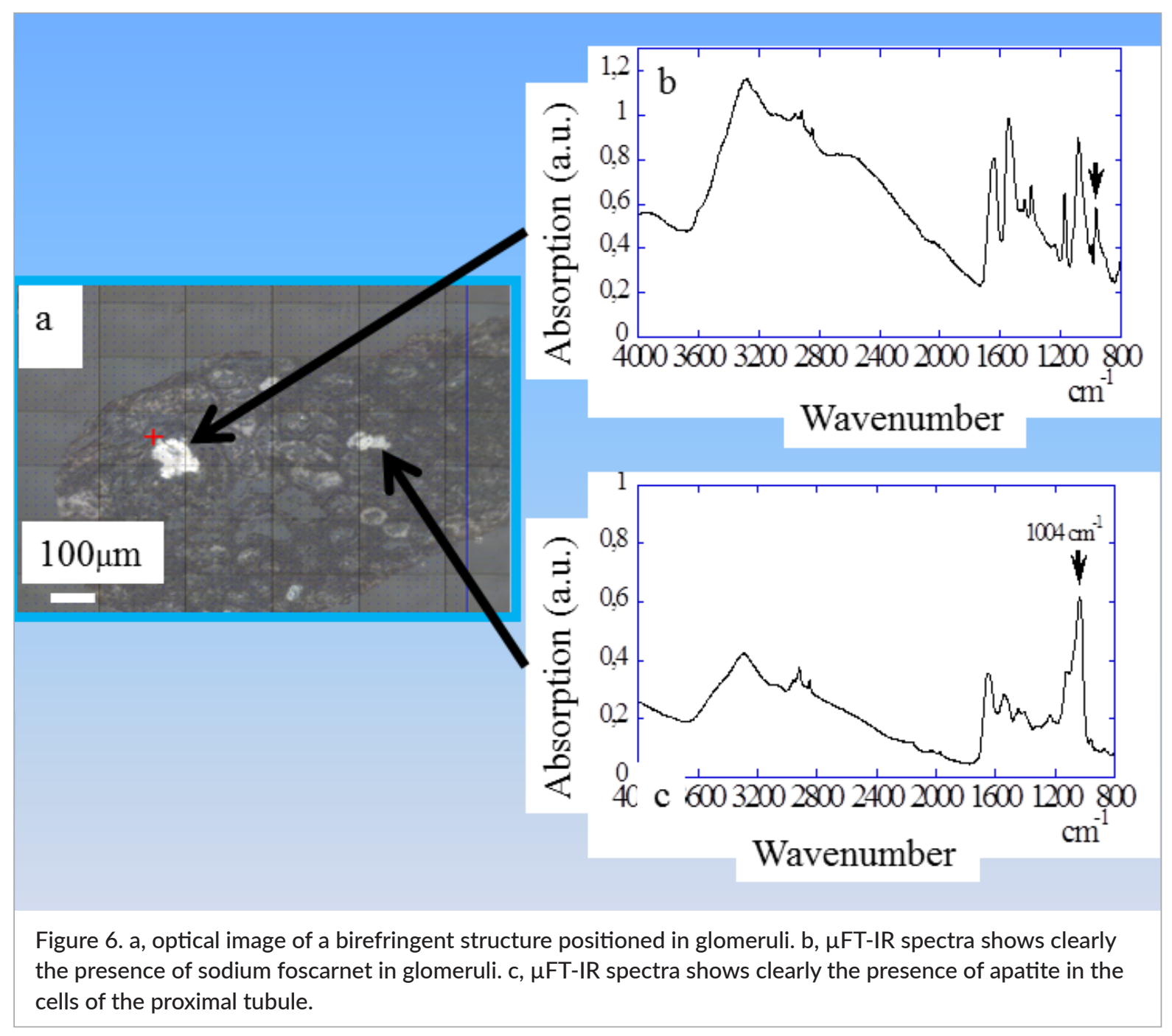


There was no evidence of malformation or obstruction. The cortex was slightly hyperechogenic. Parents are not related and they are no known nephropathies in the family.

Since she did not recover her kidney function, a biopsy was performed five weeks after acute renal failure. It revealed tubular impairment with few signs of regeneration and persistence of a discrete inflammatory infiltrate made of Iymphocytes and macrophages. They were no glomerular nor vascular lesions. By microscopic examination under polarised light, only three small $(<10 \mu \mathrm{m})$ intracellular birefringent crystals were found in the tubules (Figure 7a). Infrared microscopy using our PerkinElmer infrared spectrometer and synchrotron radiation (SMIS beamline) were performed to identify the crystals, but the results were inconclusive.

Then, we started an investigation on the DISCO beamline. ${ }^{118,121}$ We started by considering macroscopic kidney stones made of calcium oxalate monohydrate (COM). The spectrum of these kidney stones has a specific signal around $410 \mathrm{~nm}$. Then, we came back to the microcrystals present in tissues for the patient discussed just above. The spectrum obtained for the biopsy was very similar to that of the kidney stones made of COM, suggesting that the microcrystals were also made of COM (Figure 7b). Finally, we used this specific signal to obtain the distribution of oxalate in tissue (Figure 7c). Surprisingly, we observed a positive signal in almost 50\% of the tubular cells. Such observation takes into account that while IR spectroscopy is sensitive only to oxalate linked to calcium, UV-visible spectroscopy offers the possibility to gather information on oxalate linked or not to calcium. UV-visible spectroscopy opens the way to a completely new paradigm regarding ectopic calcifications. Further work is in progress on a larger number of samples.

\section{X-ray fluorescence}

In the photoelectric absorption process, the absorption of incident photons leads to the ejection of photoelectrons if the photon energy is sufficient. The atomic relaxation

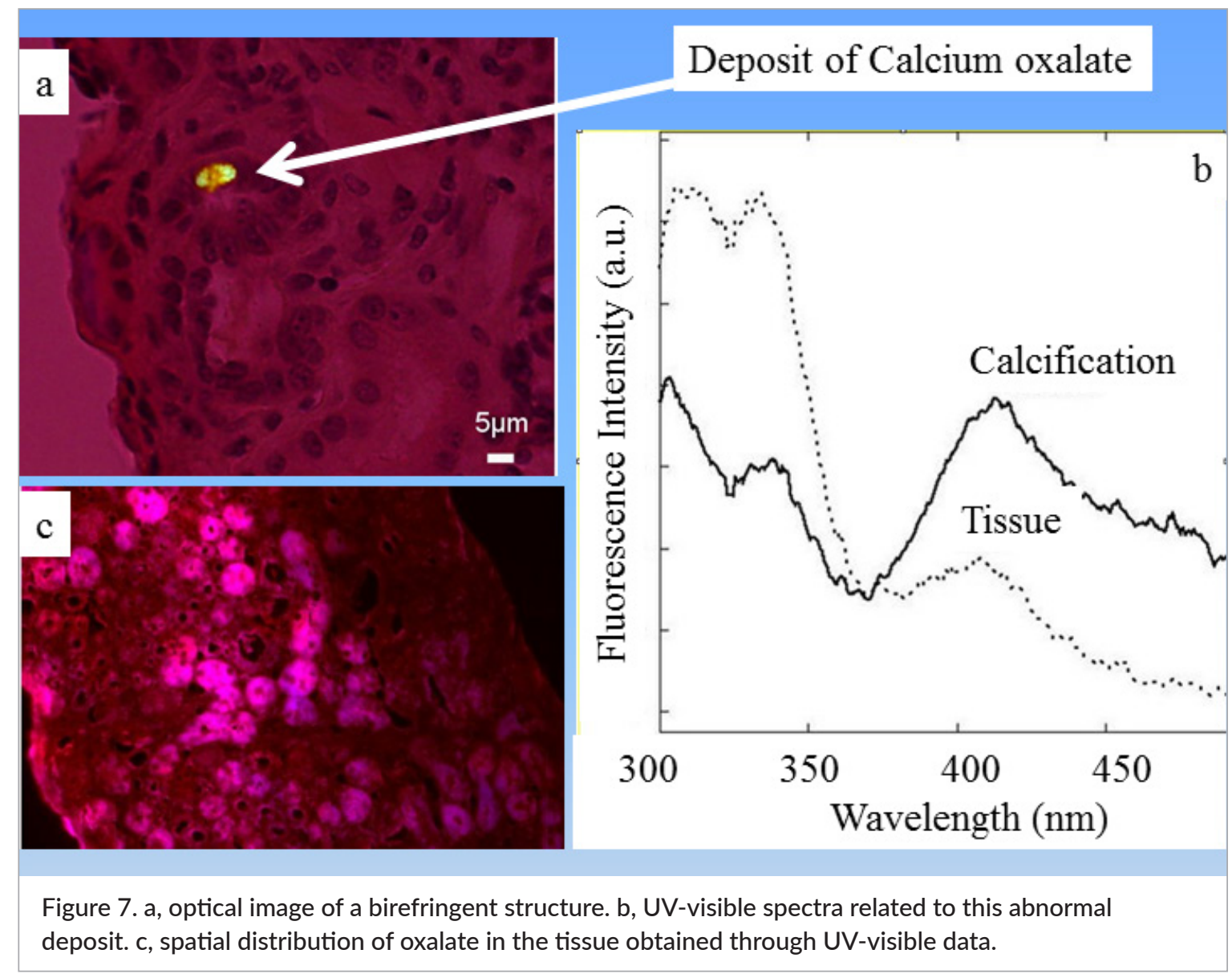


process produce XRF radiation with characteristic energies of the atom and also other photoelectrons called Auger electrons. ${ }^{42}$ The characteristic energies of the XRF radiation emitted from a sample offer the opportunity to identify unambiguously and quantify the different elements present.

This technique has been used to characterise different kinds of PC. ${ }^{122-125}$ First, note that investigation of calcification chemistry is hampered by the difficulty of quickly and systematically locating sites. A recent publication shows that XRF spectroscopy can be used to locate micro-calcifications within tissue specimens. ${ }^{126}$ Exciting results have been obtained on the ultrastructure of vascular calcifications in uremia. The complete set of data suggests that uremic micro-calcifications originate from nanocrystals, are chemically diverse and intimately associate with proteinaceous inhibitors of calcification. ${ }^{127}$ Furthermore, considering the core-shell structure of the calcifications, apoptotic bodies or matrix vesicles may serve as a calcification nidus. In another investigation, the authors examine the presence of $\mathrm{Zn}$, a trace element, in osteoarthritis (OA) cartilage and meniscus from patients undergoing total knee joint replacement for primary OA. ${ }^{128} \mathrm{~A}$ fine analysis of the data seems to show that $\mathrm{Zn}^{2+}$ cations present in the cartilage belong to two chemical species. The first may correspond to $\mathrm{Zn}^{2+}$ embedded in protein (several $\mathrm{Zn}$ metalloproteins are known to prevent calcification in biological tissues). The second may be associated with a $\mathrm{Zn}^{2+}$ trapped in or at the surface of the calcification. ${ }^{128}$ Calcification present in $\mathrm{OA}$ cartilage may significantly modify the spatial distribution of $\mathrm{Zn}^{2+}$, part of the $\mathrm{Zn}$ may be trapped in the calcification and may alter the associated biological function of $\mathrm{Zn}^{2+}$ metalloproteins. Finally, synchrotron-radiation-induced $\mu X R F$ analyses can be used to investigate the distribution of $\mathrm{Pb}$ in human joints. ${ }^{129}$ The $\mathrm{X}$-ray absorption nearedge structure (XANES) spectra collected at the $\mathrm{Pb} \mathrm{L}_{\| 1}$ edge for a microbeam positioned at the tidemark and at the trabecular bone were found to be highly correlated with the spectra of synthetic Pb-doped carbonated hydroxyapatite. The authors suggest that in both of these very different tissues $\mathrm{Pb}$ is incorporated into the hydroxyapatite structure.

Obviously, XRF has other medical applications. In our case, we have used XRF to investigate the spatial distribution of platinum-based drugs. These molecules are widely employed as anti-cancer agents because of their efficacy against a variety of tumours, but their use is limited by their nephrotoxicity. ${ }^{130}$ In the first part with a dedicated focus on mice, the cisplatin injection induced a redistribution of medullary $\mathrm{Zn}$ across the corticomedullary junction where histological lesions develop. These results were confirmed by a quantitative approach based on an evaluation of Pearson's and Manders' co-localisation coefficients. The data suggest that the spatial distribution of $\mathrm{Zn}^{2+}$ cations and more precisely its correlation with platinum can be used to evaluate the nephrotoxicity of cisplatin. This could lead to new diagnosis, physiopathological and even therapeutical approaches. ${ }^{131}$ Regarding the investigation on human biopsy, we were able to discuss the spatial repartition of $\mathrm{Pt}$ and $\mathrm{Zn}$ in RB. Therefore, $\mu \mathrm{XRF}$ could also be of major interest to decipher the mechanism beyond Pt-induced neurotoxicity, ototoxicity on human biopsy. ${ }^{132}$

\section{X-ray absorption spectroscopy (XAS)}

Due to its ability to give structural and electronic information on materials without long range order, such as clusters or molecules, ${ }^{44,45,133-135}$ XAS has made major contributions to a wide variety of medical research topics. ${ }^{136,137}$ More precisely, C.M. Weekley et al. have combined XAS and XRF techniques to assess the problem of selenium speciation in biological systems. ${ }^{138}$ More recently, XAS experiments have brought major information regarding a progressive neurodegenerative disease, namely Friedreich's ataxia. ${ }^{139}$

XAS is a direct probe of atomic distribution via electron diffraction. One of the key successes of XAS comes from the fact that last generation synchrotron sources provide a range of $\mathrm{X}$-ray energies with a microbeam that are applicable to most elements in the Periodic Table.

More precisely, we may distinguish two parts of the X-ray absorption spectrum: XANES and extended $X$-ray absorption fine structure (EXAFS). ${ }^{44,45}$ XANES corresponds to the measurement of transitions from core electronic states of the metal to the excited electronic states, while EXAFS corresponds to a transition to the continuum. XANES and EXAFS spectroscopies give complementary structural and electronic information. The XANES part describes the electronic structure and symmetry of the metal site, while the EXAFS part gives 
a fine description of numbers, types and distances to neighbouring atoms from the absorbing element. Note that for nanometre scale metallic cluster, EXAFS spectroscopy is insensitive to polydispersity. ${ }^{140}$

Regarding kidney stones, the study of RP constitutes a major research topic. Based on extensive forensic studies performed on kidney between 1935 and 1938, A. Randall, an American urologist, observed, at the tip of the renal papillae, an abnormal deposit of calcium phosphate (named RP). ${ }^{141}$ A precise observation of these RPs indicate that these PCs serve as a nidus of kidney stones. ${ }^{142,143}$ As this point, it is worth underlining that calcium oxalate stone incidence has increased worldwide during the past decades. ${ }^{143,144}$ The observation that a growing number of kidney stones are related to RP has motivated a large number of investigations based on last generation characterisation techniques (see, for example, recent References 145 and 146).

Through XAS performed at the Ca K-absorption edge, a technique specific to synchrotron radiation (Figure 8), the presence and crystallinity of the Ca phosphate phases present in RP were determined ex vivo. ${ }^{147}$ Direct structural evidence of the presence of amorphous carbonated calcium phosphate (ACCP) as a major constituent is given for the first time. This set of XANES data obtained on ex vivo samples, coherent with previous studies performed on RP extracted from kidney stones, shows that this chemical phase can be considered as one precursor in the genesis of RP. From a biochemical

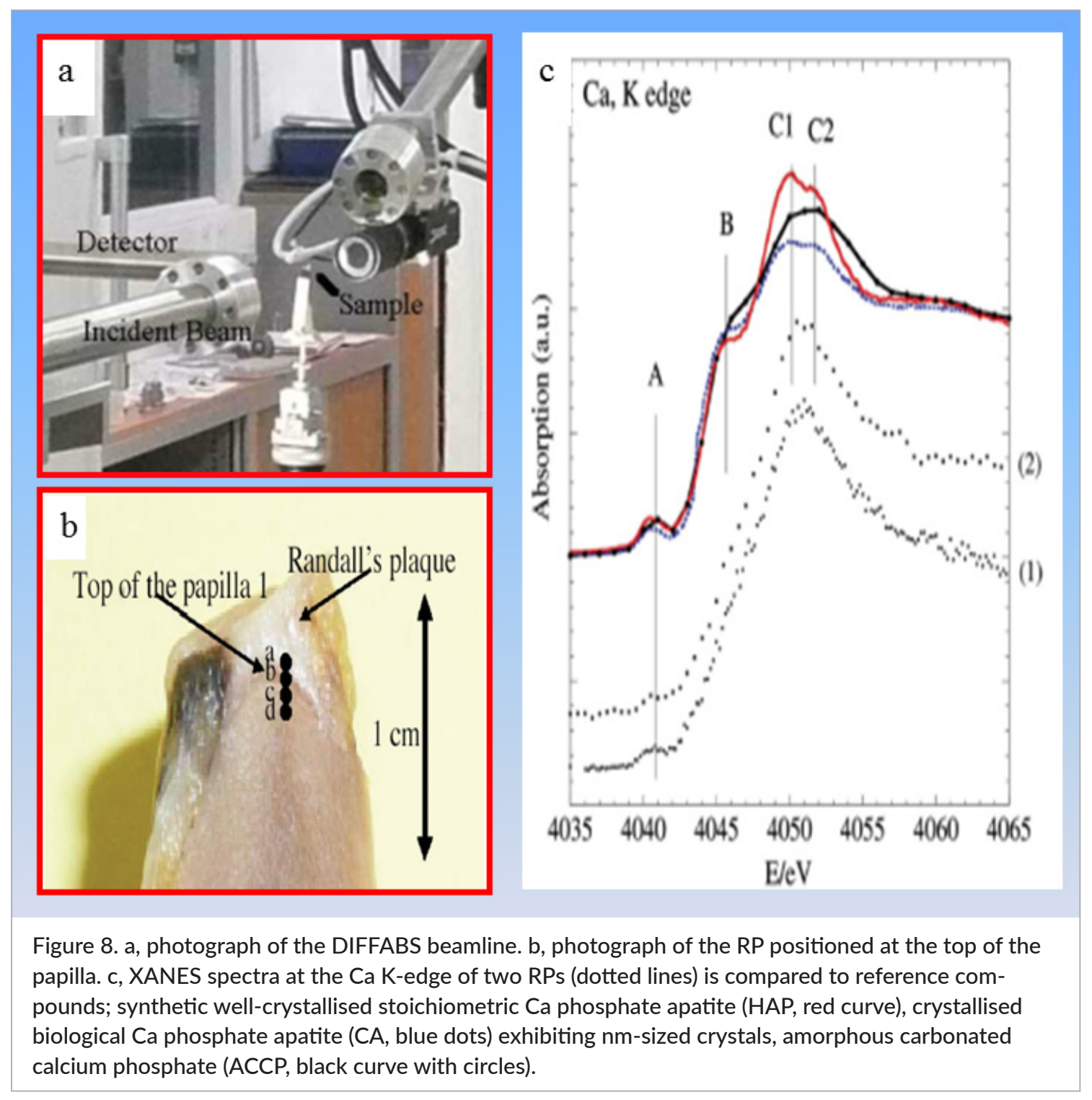


point of view, it is worth pointing out that in the kidney ACCP is considered as evidence of an oversaturation in Ca phosphate by an excess of $\mathrm{Ca}$ and/or phosphate and/ or due to a too high $\mathrm{pH}$. Such chemical compositions of RP present in increasingly young subjects raises a major question regarding public alimentation: does nutrientenriched food with calcium and vitamin D specially aimed at young children affect the physiology of the kidney? The question is open. ${ }^{148,149}$

\section{X-ray and neutron scattering}

Since the first experiment carried out using a classical vacuum tube at the beginning of the previous century, $X$-ray diffraction (XRD) has emerged to be one of the most powerful characterisation techniques in almost every field of science and technology. Many books and several review articles have been dedicated to the numerous methods of characterisation linked to $X$-ray scattering. ${ }^{43,150}$ Basically, scattering techniques can be used either to determine the crystal structure or the chemical composition of the samples through the powder diffraction bank data file. As previously underlined, FT-IR spectroscopy can also give the chemical composition, but XRD and FT-IR display advantages as well as limitations. XRD gives the size of the crystal for each chemical phase which are identified, but this technique is only sensitive to chemical phases with long range order. ${ }^{43} \mathrm{FT}-\mathrm{IR}$ is sensitive to amorphous and crystallised compounds and gives some important structural characteristics such as the carbonate level of apatite. This structural characteristic is of major importance to establish a possible infection involved in stone formation.

Regarding kidney stones, we have used scattering techniques to determine structural characteristics of different unknown chemical phases present in kidney stones. ${ }^{151-153}$ The identification of a new compound in kidney stones is relevant in clinical practice. Such a new chemical phase is often related to a new kidney disease.

In order to determine the crystal's size in the case of kidney stones made of COM, ${ }^{154}$ cystine $^{83}$ and uric acid, ${ }^{155}$ we have used neutron scattering. ${ }^{156}$ More generally, because neutrons do not significantly damage biological solids such as kidney stones, they offer the opportunity to investigate bulk biological samples, whether as an aqueous solution, a solid, a powder or a crystal. Neutron scattering uniquely complements other characterisation techniques, and together with X-ray synchrotron analysis, is considered among the most useful microscopic probes of matter available today. ${ }^{157}$ Unlike X-rays, they do not interact with the electronic cloud of an atom, but with its nucleus: the strength and character of this neutron-nucleus interaction is characterised by the so-called neutron scattering length. This neutron scattering length varies irregularly from one nucleus to another. In particular, this parameter is quite significant for light elements like hydrogen, carbon, nitrogen or oxygen, which are almost invisible to X-rays. Neutrons like photons and electrons constitute thus an important probe in the investigation of the matter and especially in the location and dynamics of protons, an essential aspect in many biological processes.

Among the different key results we have obtained using neutrons as a probe, we will discuss the ones related to uric acid kidney stones. ${ }^{155}$ As noticed previously, recent epidemiological investigations have identified an association between type 2 diabetes and uric acid kidney stones. ${ }^{114,155}$ Such a relationship is more apparent in women than in men. Through powder neutron diffraction, ${ }^{156,157}$ we have shown that particle sizes of uric acid kidney stones were significantly different between male and female patients $(84.7 \mathrm{~nm} \pm 5.3 \mathrm{~nm}$ vs $140.2 \mathrm{~nm} \pm 6.7 \mathrm{~nm}, \mathrm{p}=0.000003$ ). When we consider male and female patients with type 2 diabetes, this structural difference between male and female vanished (76.1 nm $\pm 3.9 \mathrm{~nm}$ vs $78.8 \mathrm{~nm} \pm 4.2 \mathrm{~nm}$, not significant). We try to explain these structural data obtained on kidney stones and based on neutron scattering experiment, in line with observations regarding epidemiological data on arguments based on supersaturation.

\section{Conclusion and perspectives}

This mini-review dedicated to research performed on PC shows clearly an exciting meeting between physics, chemistry and medicine. Due the complexity of such biological entities which contain organic and inorganic parts in which trace elements are present, different in-lab characterisation techniques are used. Analysis at the micrometre scale is carried out by techniques using synchrotron radiation as a probe, which gives the opportunity to describe the structural characteristics of human calcification at the nanometre scale. Note that we have also performed very exciting investigations 
on cells ${ }^{158}$ and mice. ${ }^{84,131,159-161}$ Finally, it is worth underlining that fundamental research performed on the adsorption of molecules on clusters is also carried out. ${ }^{162-165}$ Such a fundamental approach will help us to understand how molecules interact with nanocrystals and modify their morphology.

Inconclusion, results obtained with synchrotron radiation have been used to develop new diagnostic methods and to understand more deeply the pathogenesis process of PC. Second, a technology transfer has been done in order to perform similar experiments at the hospital. It is worth underlining that more than 1600 kidney biopsies have been characterised following the publication in PLOS ONE dedicated to kidney biopsies in close collaboration with SOLEIL Synchrotron. ${ }^{27}$ To attain this goal, we performed the measurements with young doctors, namely Dr E. Bouderlique (Nephrologist), Dr F. Brunet-Possenti (Dermatologist), Dr X. Carpentier (Urologist), Dr R. Coscas (Cardiologist), Dr H. Colboc (Dermatologist), Dr E. Estève (Nephrologist), Dr A. Gauffenik (Rheumatologist), Dr J. Guerlain (Otorhinolaryngologist), Dr R. Kormann (Nephrologist), Dr M. Livrozet (Nephrologist), Dr Y. Luque (Nephrologist), Dr Ch. Nguyen (Rheumatologist), Dr B. Pradère (Urologist), Dr C. St Jacques (Nephrologist), Dr C. Verrier (Urologist) and Dr V. Masson-Behar (Rheumatologist), who finally have the opportunity to define completely new research topics.

\section{Acknowledgements}

We thank Dr X. Carpentier (Nice Hospital), Dr Ch. Chappard (Lariboisière Hospital), Prof. P. Conort (La Pitié-Salpetrière Hospital), Dr P. Dorfmüller (La PitiéSalpetrière Hospital), Dr E. Estève (Tenon Hospital), Prof. D. Hannouche (Lariboisière Hospital), Dr J.P. Haymann (Tenon Hospital), Prof. P. Jungers (Necker Hospital), Prof. B. Knebelman (Necker Hospital), Dr E.A. Korng (Lariboisière Hospital), Dr E. Letavernier (Tenon Hospital), Prof. F. Liote (Lariboisière Hospital), Dr M. Livrozet (Tenon Hospital), Prof. M. Mathonnet (Limoges Hospital), Prof. P. Meria (Saint-Louis Hospital), Dr C. Nguyen (Lariboisière Hospital), Dr J. Rode (Tenon Hospital), Prof. P. Ronco (Tenon Hospital), Dr I. Tostivint (La Pitié-Salpetrière Hospital), Prof. O. Traxer (Tenon Hospital) and Prof. J.C. Williams (Department of Anatomy and Cell Biology, Indiana University School of Medicine,
Indianapolis, Indiana, USA) for providing samples and useful discussions.

Also, regarding the physicochemistry, this research could not have been performed without the scientific advice of Dr P.-A. Albouy (LPS), Dr G. André (LLB), Dr A. Bianchi (INSERM-U7561), Dr P. Chevallier (LURE), Dr A. Cousson (LLB), Dr P. Dumas (SOLEIL Synchrotron), Dr E. El Kaim (SOLEIL Synchrotron), Dr B. Fayard (LPS-ESRF), Dr E. Foy (Laboratoire Pierre-Süe), Dr J.-L. Hazemann (ESRF), Dr L. Hennet (CEMHTI), Dr A. Lebail (Laboratoire des Fluorures), Dr F. Lenaour (Hôpital Paul Brousse), Dr O. Mathon (ESRF), Dr K. Medjoubi (SOLEIL Synchrotron), Dr G. Matzen (CEMHTI), Dr C. Mocuta (SOLEIL Synchrotron), Dr R. Papoular (CEA), Dr P. Reboul, (UMR 7561), Dr M. Réfrégiers (SOLEIL Synchrotron), Dr S. Reguer (SOLEIL Synchrotron), Dr S. Rouzière (LPS), Dr J.-P. Samama (SOLEIL Synchrotron), Dr C. Sandt (SOLEIL Synchrotron), Dr A. Somogi (SOLEIL Synchrotron), Dr D. Thiaudière (SOLEIL Synchrotron), Dr E. Véron (CEMHTI) and Dr R. Weil (LPS).

This work was supported by the Physics and Chemistry Institutes of CNRS and by contracts ANR-09-BLAN-0120-02, ANR-12-BS08-0022, ANR13JSV10010-01, convergence UPMC CVG1205 and CORDDIM-2013-COD130042. The authors are grateful to the SOLEIL Synchrotron Facility and the Leon Brillouin laboratory for beam time allocation.

\section{References}

1. D. Bazin, M. Daudon, P. Chevallier, S. Rouzière, E. Elkaim, D. Thiaudiere, B. Fayard, E. Foy, P. A. Albouy, G. André, G. Matzen and E. Véron, "[Synchrotron radiation techniques for structural characterisation of biological entities: an example with renal stone analysis]", Ann. Biol. Clin. (Paris) 64(2), 125 (2006).

2. D. Bazin, M. Daudon, C. Combes and C. Rey, "Characterization and some physicochemical aspects of pathological microcalcifications", Chem. Rev. 112(10), 5092 (2012). https://doi.org/10.1021/ cr200068d

3. M. Daudon and D. Bazin, "New techniques to characterize kidney stones and Randall's plaque", in Urolithiasis: Basic Science and Clinical Practice, Ed by J.J. Talati, H.G. Tiselius, D.M. Albala and Z. Ye. Springer, pp. 683-707 (2012). 
4. D. Bazin and M. Daudon, "Pathological calcifications and selected examples at the medicine-solid-state physics interface", J. Phys. D Appl. Phys. 45(38), 383001 (2012). https://doi.org/10.1088/00223727/45/38/383001

5. S. Udomkarnjananun, K. Kongnatthasate, K. Praditpornsilpa, S. Eiam-Ong, B.L. Jaber and P. Susantitaphong, "Treatment of calciphylaxis in CKD: A systematic review and meta-analysis", Kidney Int. Rep. 4(2), 231 (2018). https://doi.org/10.1016/j. ekir.2018.10.002

6. A. Corrado, F. D'Onofrio, N. Santoro, N. Melillo and F.P. Cantatore, "Pathogenesis, clinical findings and management of acute and chronic gout", Minerva Med. 97(6), 495 (2006).

7. X. Fei, W. Jin, S. Hua and Y. Song, "Prospective study on association of prostatic calcifications with clinical symptoms and results of treatment in men with type III prostatitis", Sci. Rep. 7(1), 5234 (2017). https://doi.org/10.1038/s41598-017-05550-3

8. M. Scimeca, R. Bonfiglio, F. Varone, S. Ciuffa, A. Mauriello and E. Bonanno, "Calcifications in prostate cancer: An active phenomenon mediated by epithelial cells with osteoblast-phenotype", Microsc. Res. Tech. 81(7), 745 (2018). https://doi.org/10.1002/ jemt.23031

9. L.D. Truong, J. Cartwright and L. Alpert, "Calcium oxalate in breast lesions biopsied for calcification detected in screening mammography: incidence and clinical significance", Mod. Pathol. 5(2), 146 (1992).

10. T. Oyama, T. Sano, T. Hikino, Q. Xue, K. lijima, T. Nakajima and F. Koerner, "Microcalcifications of breast cancer and atypical cystic lobules associated with infiltration of foam cells expressing osteopontin", Virchows Arch. 440(3), 267 (2002). https://doi. org/10.1007/s004280100501

11. R. Baker, K.D. Rogers, N. Shepherd and N. Stone, "New relationships between breast microcalcifications and cancer", Br. J. Cancer 103(7), 1034 (2010). https://doi.org/10.1038/sj.bjc.6605873

12. M. Daudon, C.A. Bader and P. Jungers, "Urinary calculi: review of classification methods and correlations with etiology", Scanning Microsc. 7(3), 1081 (1993).

13. M. Daudon, P. Jungers and D. Bazin, "Stone morphology: Implication for pathogenesis", Renal Stone Disease II 1049, 199 (2008). https://doi. org/10.1063/1.2998023
14. P.M. Ferraro, A. Ticinesi, T. Meschi, A. Rodgers, F. Di Maio, P. Fulignati, L. Borghi and G. Gambaro, "Short-term changes in urinary relative supersaturation predict recurrence of kidney stones: A tool to guide preventive measures in urolithiasis", J. Urol. 200(5), 1082 (2018). https://doi.org/10.1016/j. juro.2018.06.029

15. M. Daudon, V. Frochot, D. Bazin and P. Jungers, "Crystalluria analysis improves significantly etiologic diagnosis and therapeutic monitoring of nephrolithiasis", C.R. Chim. 19(11-12), 1514 (2016). https://doi. org/10.1016/j.crci.2016.04.010

16. E. Letavernier, D. Bazin and M. Daudon, "Randall's plaque and kidney stones: Recent advances and future challenges", C.R. Chim. 19(11-12), 1456 (2016). https://doi.org/10.1016/j.crci.2014.12.005

17. C. Bardet, F. Courson, Y. Wu, M. Khaddam, B. Salmon, S. Ribes, J. Thumfart, P.M. Yamaguti, G.Y. Rochefort, M.-L. Figueres, T. Breiderhoff, A. GarciaCastaño, B. Vallée, D. Le Denmat, B. Baroukh, T. Guilbert, A. Schmitt, J.-M. Massé, D. Bazin, G. Lorenz, M. Morawietz, J. Hou, P. Carvalho-Lobato, M.C. Manzanares, J.-C. Fricain, D. Talmud, R. Demontis, F. Neves, D. Zenaty, A. Berdal, A. Kiesow, M. Petzold, S. Menashi, A. Linglart, A.C. Acevedo, R. Vargas-Poussou, D. Müller, P. Houillier and C. Chaussain, "Claudin-16 deficiency impairs tight junction function in ameloblasts, leading to abnormal enamel formation", J. Bone Miner. Res. 31(3), 498 (2016). https://doi.org/10.1002/jbmr.2726

18. D. Bazin, C. Chappard, C. Combes, X. Carpentier, S. Rouzière, G. André, G. Matzen, M. Allix, D. Thiaudière, S. Reguer, P. Jungers and M. Daudon, "Diffraction techniques and vibrational spectroscopy opportunities to characterise bones", Osteoporos. Int. 20(6), 1065 (2009). https://doi.org/10.1007/s00198009-0868-3

19. Ch. Chappard, G. André, M. Daudon and D. Bazin, "Analysis of hydroxyapatite crystallites in subchondral bone by Fourier transform infrared spectroscopy and powder neutron diffraction methods", C.R. Chim. 19(11-12), 1625 (2016). https://doi. org/10.1016/j.crci.2015.03.015

20. M. Daudon and D. Bazin, "When the synchrotron radiations highlight the Randall's plaques and kidney concretions", J. Phys. Conf. Ser. 425(2), 022006 (2013). https://doi.org/10.1088/17426596/425/2/022006 
21. S. Brachemi and G. Bollée, "Renal biopsy practice: What is the gold standard?", World J. Nephrol. 3(4), 287 (2014). https://doi.org/10.5527/wjn.v3.i4.287

22. P. Stratta, C. Canavese, M. Marengo, P. Mesiano, L. Besso, M. Quaglia, D. Bergamo, G. Monga, G. Mazzucco and G. Ciccone, "Risk management of renal biopsy: 1387 cases over 30 years in a single centre", Eur. J. Clin. Invest. 37(12), 954 (2007). https://doi.org/10.1111/j.1365-2362.2007.01885.x

23. D. Bazin and M. Daudon, "Les pathologies microcristallines et les techniques de physicochimie: quelques avancées", Ann. Biol. Clin. (Paris) 73, 517 (2015). https://doi.org/10.1684/abc.2015.1070

24. L.F. Bonewald, S.E. Harris, J. Rosser, M.R. Dallas, S.L. Dallas, N.P. Camacho, B. Boyan and A. Boskey, "von Kossa staining alone is not sufficient to confirm that mineralization in vitro represents bone formation", Calcif. Tissue Int. 72(5), 537 (2003). https://doi. org/10.1007/s00223-002-1057-y

25. P. Cartier, M. Hamet and J. Hamburger, "Une nouvelle maladie nétabolique: le déficit complete en adénine-phosphoribosyltransférase avec lithiase de 2,8-dihydroxyadénine", C.R. Acad. Sci. III 279(10), 883 (1974).

26. https://www.lepoint.fr/futurapolis/ diagnostiquer-plus-tot-pour-eviter-la-greffe-durein-29-11-2011-1401872_427.php

27. A. Dessombz, D. Bazin, P. Dumas, C. Sandt, J. Sule-Suso and M. Daudon, "Shedding light on the chemical diversity of ectopic calcifications in kidney tissues: diagnostic and research aspects", PLoS One 6(11), e28007 (2011). https://doi.org/10.1371/ journal.pone.0028007

28. A. Lionet, M. Haeck, A. Garstka, V. Gnemmi, D. Bazin, E. Letavernier, J.-Ph. Haymann, Ch. Noel and M. Daudon, "First investigation on microcrystalline pathologies of kidney allografts through cellular scale physicochemical techniques", C.R. Chim. 19(11-12), 1542 (2016). https://doi.org/10.1016/j. crci.2015.09.016

29. W. Thomlinson, "Medical applications of synchrotron radiation", Nucl. Instrum. Meth. Phys. Res. A 319(1-3), 295 (1992). https://doi. org/10.1016/0168-9002(92)90569-P

30. B. Gilbert, G. Margaritondo, D. Mercanti, P. Casalborea and G. De Stasio, "Synchrotron spectromicroscopy in medicine and biology", J. Alloys
Compd. 328(1-2), 8 (2001). https://doi.org/10.1016/ S0925-8388(01)01323-8

31. P. Suortti and W. Thomlinson, "Medical applications of synchrotron radiation", Phys. Med. Biol. 48(13), R1 (2003). https://doi.org/10.1088/00319155/48/13/201

32. D. Bazin, X. Carpentier, O. Traxer, D. Thiaudière, A. Somogyi, S. Reguer, G. Waychunas, P. Jungers and M. Daudon, "Very first tests on SOLEIL regarding the $Z n$ environment in pathological calcifications made of apatite determined by $X$-ray absorption spectroscopy", J. Synchrotron Radiat. 15(Pt 5), 506 (2008). https://doi.org/10.1107/ $\underline{\mathrm{S} 0909049508014556}$

33. H. Elleaume, S. Fiedler, F. Estève, B. Bertrand, A.M. Charvet, P. Berkvens, G. Berruyer, T. Brochard, G. Le Duc, C. Nemoz, M. Renier, P. Suortti, W. Thomlinson and J.F. Le Bas, "First human transvenous coronary angiography at the European Synchrotron Radiation Facility", Phys. Med. Biol. 45(9), L39 (2000). https:// doi.org/10.1088/0031-9155/45/9/102

34. J.-F. Adam, C. Nemoz, A. Bravin, S. Fiedler, S. Bayat, S. Monfraix, G. Berruyer, A.M. Charvet, J.-F. Le Bas, $H$. Elleaume and F. Estève, "High-resolution bloodbrain barrier permeability and blood volume imaging using quantitative synchrotron radiation computed tomography: study on an F98 rat brain glioma", J. Cereb. Blood Flow Metab. 25(2), 145 (2005). https:// doi.org/10.1038/sj.jcbfm.9600017

35. B. Pouyatos, C. Nemoz, T. Chabrol, M. Potez, E. Bräuer, L. Renaud, K. Pernet-Gallay, F. Estève, O. David, P. Kahane, J.A. Laissue, A. Depaulis and R. Serduc, "Synchrotron X-ray microtransections: a non invasive approach for epileptic seizures arising from eloquent cortical areas", Sci. Rep. 6(1), 27250 (2016). https://doi.org/10.1038/srep27250

36. M. Daudon, O. Traxer, P. Jungers and D. Bazin, "Stone morphology suggestive of Randall's plaque", Renal Stone Disease 900, 26 (2007). https://doi. org/10.1063/1.2723556

37. M. Daudon, H. Bouzidi and D. Bazin, "Composition and morphology of phosphate stones and their relation with etiology", Urol. Res. 38(6), 459 (2010). https://doi.org/10.1007/s00240-010-0320-3

38. M. Daudon, A. Dessombz, V. Frochot, E. Letavernier, J.-Ph. Haymann, P. Jungers and D. Bazin, "Comprehensive morpho-constitutional analysis of urinary stones improves etiological diagnosis and 
therapeutic strategy of nephrolithiasis", C.R. Chim. 19(11-12), 1470 (2016). https://doi.org/10.1016/j. crci.2016.05.008

39. D. Bazin, J.-P. Haymann, E. Letavernier, J. Rode and M. Daudon, "PPathological calcifications: a medical diagnosis based on their physicochemical properties]", Presse Med. 43(2), 135 (2014). https://doi. org/10.1016/j.lpm.2013.02.333

40. H.G. Wells, "Pathological calcification", J. Med. Res. 14(3), 491 (1906).

41. E. Bonucci, Biological Calcification, Normal and Pathological Processes in the Early Stages. Springer Verlag, Berlin (2007).

42. G. Sagnac, "Rayons secondaires dérivés des rayons de Rontgen". Thesis, Faculté des sciences de Paris (1900).

43. A. Guinier, X-Ray Diffraction in Crystals, Imperfect Crystals and Amorphous Bodies. Dunod, Paris (1956).

44. D.E. Sayers, E.A. Stern and F. Lytle, "New technique for investigating noncrystalline structures: Fourier analysis of the extended X-ray-absorption fine structure", Phys. Rev. Lett. 27(18), 1204 (1971). https://doi. org/10.1103/PhysRevLett.27.1204

45. F.W. Lytle, D.E. Sayers and E.A. Stern, "Extended $x$-ray-absorption fine-structure technique. II. Experimental practice and selected results", 11(12), 4825 (1975). https://doi.org/10.1103/ PhysRevB.11.4825

46. L.M. Miller and P. Dumas, "From structure to cellular mechanism with infrared microspectroscopy", Curr. Opin. Struct. Biol. 20(5), 649 (2010). https://doi. org/10.1016/j.sbi.2010.07.007

47. M. Daudon and D. Bazin, "Vibrational spectroscopies to investigate concretions and ectopic calcifications for medical diagnosis", C.R. Chim. 19(11-12), 1416 (2016). https://doi.org/10.1016/j. crci.2016.05.011

48. F. Jamme, S. Villette, A. Giuliani, V. Rouam, F. Wien, B. Lagarde and M. Réfrégiers, "Synchrotron UV fluorescence microscopy uncovers new probes in cells and tissues", Microsc. Microanal. 16(5), 507 (2010). https://doi.org/10.1017/S1431927610093852

49. S. Kaščáková, L. Maigre, J. Chevalier, M. Réfrégiers and J.-M. Pagès, "Antibiotic transport in resistant bacteria: synchrotron UV fluorescence microscopy to determine antibiotic accumulation with single cell resolution", PLoS One 7(6), e38624 (2012). https:// doi.org/10.1371/journal.pone.0038624
50. R. Coscas, M. Bensussan, M.-P. Jacob, L. Louedec, Z. Massy, J. Sadoine, M. Daudon, C. Chaussain, D. Bazin and J.-B. Michel, "Free DNA precipitates calcium phosphate apatite crystals in the arterial wall in vivo", Atherosclerosis 259, 60 (2017). https://doi. org/10.1016/j.atherosclerosis.2017.03.005

51. Y. Chelyshev, M. Gafurov, I. Ignatyev, A. Zanochkin, G. Mamin, B. Sorokin, A. Sorokina, N. Lyapkalo, N. Gizatullina, Y. Mukhamedshina and S. Orlinskii, "Paramagnetic manganese in the atherosclerotic plaque of carotid arteries", BioMed Res. Int. 2016, 3706280 (2016). https://doi. org/10.1155/2016/3706280

52. A. Ben Lakhdar, M. Daudon, M.C. Matthieu, A. Kellum, C. Balleyguier and D. Bazin, "Underlining the complexity of the structural and chemical characteristics of ectopic calcifications in breast tissues through FE-SEM and $\mu F T$-IR spectroscopy", C.R. Chim. 19(11-12), 1610 (2016). https://doi. org/10.1016/j.crci.2015.03.011

53. J.A.M.R. Kunitake, S. Choi, K.X. Nguyen, M.M. Lee, F. He, D. Sudilovsky, P.G. Morris, M.S. Jochelson, C.A. Hudis, D.A. Muller, P. Fratzl, C. Fischbach, A. Masic and L.A. Estroff, "Correlative imaging reveals physiochemical heterogeneity of microcalcifications in human breast carcinomas", J. Struct. Biol. 202(1), 25 (2018). https://doi.org/10.1016/j.jsb.2017.12.002

54. R. Scott, C. Kendall, N. Stone and K. Rogers, "Elemental vs. phase composition of breast calcifications", Sci. Rep. 7(1), 136 (2017). https://doi. org/10.1038/s41598-017-00183-y

55. H.A. Almarshad, S.M. Badawy and A.F. Alsharari, "Structural characterization of gallbladder stones using energy dispersive $\mathbf{X}$-ray spectroscopy and $X$-ray diffraction", Comb. Chem. High Throughput Screen. 21(7), 495 (2018). https://doi.org/10.2174/13 86207321666180913113803

56. C.-L. Cheng, H.-H. Chang, T.-H. Chen, P.-J. Tsai, Y.-T. Huang, P.-J. Huang and S.-Y. Lin, "Spectral and morphological classification of different chronic and acute Taiwanese gallstones via FTIR, SEM and ESEM-EDX microanalyses", Dig. Liver Dis. 48(5), 519 (2016). https://doi.org/10.1016/j.dld.2016.01.010

57. M. Olaya-C, S. Aldana-M, M. Maya-G and F. Gil, "Hepatic calcifications in fetal population studied by autopsies in Bogota, Colombia", J. Dev. Orig. Health Dis. 8(5), 613 (2017). https://doi.org/10.1017/ S2040174417000356 
58. C.J. Cros, D. Bazin, A. Kellum, V. Rebours and M. Daudon, "Investigation at the micrometer scale of pancreatic calcifications in chronic pancreatitis by HFT-IR spectroscopy and field emission scanning electron microscopy", C.R. Chim. 19(11-12), 1642 (2016). https://doi.org/10.1016/j.crci.2015.06.015

59. C.S. Pramanik, S. Ghosh, A. Roya and A.K. Mukherjee, "Biomineralization in human pancreas: A combined infrared-spectroscopy, scanning electron microscopy, x-ray Rietveld analysis and thermogravimetric study", J. Mater. Res. 31(3), 328 (2016). https://doi.org/10.1557/jmr.2015.363

60. A. Dessombz, P. Méria, D. Bazin and M. Daudon, "Prostatic stones: evidence of a specific chemistry related to infection and presence of bacterial imprints", PLoS One 7(12), e51691 (2012). https://doi. org/10.1371/journal.pone.0051691

61. A. Dessombz, P. Méria, D. Bazin, E. Foy, S. Rouzière, R. Weil and M. Daudon, "[Revisiting the chemical diversity in prostatic calculi: a SEM and FT-IR investigation]", Prog. Urol. 21(13), 940 (2011). https://doi. org/10.1016/j.purol.2011.04.003

62. Y. Li, D.G. Reid, D. Bazin, M. Daudon and M.J. Duer, "Solid state NMR of salivary calculi: Prolinerich salivary proteins, citrate, polysaccharides, lipids, and organic-mineral interactions", C.R. Chim. 19(11-12), 1665 (2016). https://doi.org/10.1016/j. crci.2015.07.001

63. E.M. Mathonnet, A. Dessobz, D. Bazin, R. Weil, F. Triponez, M. Pusztaszeri and M. Daudon, "Chemical diversity of calcifications in thyroid and hypothetical link to disease", C.R. Chim. 19(11-12), 1672 (2016). https://doi.org/10.1016/j.crci.2015.02.008

64. C.-L. Cheng, H.-H. Chang, S.-C. Ko, P.-J. Huang and S.-Y. Lin, "Dual-energy computed tomography gemstone spectral imaging: A novel technique to determine human cardiac calculus composition", J. Comput. Assist. Tomogr. 40(2), 283 (2016). https://doi. org/10.1097/RCT.0000000000000355

65. C. Nguyen, H.-K. Ea, D. Bazin, M. Daudon and F. Lioté, "Osteoarthritis, a basic calcium phosphate crystal-associated arthropathy? Comment on the article by Fuerst et al.", Arthritis Rheum. 62(9), 2829 (2010). https://doi.org/10.1002/art.27576

66. H.-K. Ea, C. Nguyen, D. Bazin, A. Bianchi, J. Guicheux, P. Reboul, M. Daudon and F. Lioté, "Articular cartilage calcification in osteoarthritis: insights into crystal-induced stress", Arthritis Rheum. 63(1), 10 (2011). https://doi.org/10.1002/art.27761 67. C. Nguyen, H.K. Ea, D. Thiaudière, S. Reguer, D. Hannouche, M. Daudon, F. Lioté and D. Bazin, "Calcifications in human osteoarthritic articular cartilage: ex vivo assessment of calcium compounds using XANES spectroscopy", J. Synchrotron Radiat. 18(Pt 3), 475 (2011). https://doi.org/10.1107/ S0909049511006984

68. H.-K. Ea, V. Chobaz, C. Nguyen, S. Nasi, P. van Lent, M. Daudon, A. Dessombz, D. Bazin, G. McCarthy, B. Jolles-Haeberli, A. Ives, D. Van Linthoudt, A. So, F. Lioté and N. Busso, "Pathogenic role of basic calcium phosphate crystals in destructive arthropathies", PLoS One 8(2), e57352 (2013). https://doi. org/10.1371/journal.pone.0057352

69. M. Shen, P.S. Lajos, D. Farge, M. Daudon, S.M. Carpentier, L. Chen, B. Martinet and A.F. Carpentier, "Infrared spectroscopy in the evaluation of the process of calcification of valvular bioprostheses", Ann. Thorac. Surg. 66(6), S236 (1998). https://doi. org/10.1016/S0003-4975(98)01102-3

70. W. Peters, K. Pritzker, D. Smith, V. Fornasier, D. Holmyard, S. Lugowski, M. Kamel and F. Visram, "Capsular calcification associated with silicone breast implants: incidence, determinants, and characterization", Ann. Plast. Surg. 41(4), 348 (1998). https://doi. org/10.1097/00000637-199810000-00002

71. C. Poulard, A. Dessombz, M. Daudon and D. Bazin, "Duration of JJ stent in situ is critical: An ultrastructural and mechanical investigation", C.R. Chim. 19(11-12), 1597 (2016). https://doi.org/10.1016/j. crci.2016.10.002

72. W. Kram, N. Buchholz and O.W. Hakenberg, "Ureteral stent encrustation. Pathophysiology", Arch. Esp. Urol. 69(8), 485 (2016).

73. S.K. Pandey, L. Werner, D.J. Apple and M. Kaskaloglu, "Hydrophilic acrylic intraocular lens optic and haptics opacification in a diabetic patient: bilateral case report and clinicopathologic correlation", Ophthalmology 109(11), 2042 (2002). https:// doi.org/10.1016/S0161-6420(02)01265-4

74. E.J. Espinosa-Ortiz, B.H. Eisner, D. Lange and R. Gerlach, "Current insights into the mechanisms and management of infection stones", Nat. Rev. Urol. 16(1), 35 (2019). https://doi.org/10.1038/s41585$\underline{018-0120-z}$ 
75. R.F. Cox and M.P. Morgan, "Microcalcifications in breast cancer: Lessons from physiological mineralization", Bone 53(2), 437 (2013). https://doi. org/10.1016/j.bone.2013.01.013

76. M. Daudon, V. Frochot, D. Bazin and P. Jungers, "Drug-induced kidney stones and crystalline nephropathy: pathophysiology, prevention and treatment", Drugs 78(2), 163 (2018). https://doi. org/10.1007/s40265-017-0853-7

77. P. Cochat, "Primary hyperoxaluria type 1", Kidney Int. 55(6), 2533 (1999). https://doi.org/10.1046/j.15231755.1999.00477.x

78. M. Daudon, P. Jungers and D. Bazin, "Peculiar morphology of stones in primary hyperoxaluria", N. Engl. J. Med. 359(1), 100 (2008). https://doi.org/10.1056/ NEJMc0800990

79. E. Königsberger and L.C. Königsberger, Biomineralization, Medical Aspects of Solubility. Wiley Interscience, New York (2006).

80. P.M. Ferraro and G.C. Curhan, "Serum uric acid and risk of kidney stones", Am. J. Kidney Dis. 70(2), 158 (2017). https://doi.org/10.1053/j.ajkd.2017.05.004

81. E. Letavernier, O. Traxer, J.-P. Haymann, D. Bazin and M. Daudon, "Cystinuria", Prog. Urol. 22, F119 (2012). https://doi.org/10.1016/j.fpurol.2012.06.002

82. B. Hannache, D. Bazin, A. Boutefnouchet and M. Daudon, "Effet de dissolution des extraits de plantes médicinales sur les calculs rénaux de cystine: étude à l'échelle mésoscopique", Prog. Urol. 22, 577 (2012). https://doi.org/10.1016/j.purol.2012.06.001

83. D. Bazin, M. Daudon, G. André, R. Weil, E. Véron and G. Matzen, "Therapy modifies cystine kidney stones at the macroscopic scale. Does such alterations exist at the mesoscopic \& nanometer scale?", J. Appl. Cryst. 47(2), 719 (2014). https://doi. org/10.1107/S1600576714004658

84. M. Livrozet, S. Vandermeersch, L. Mesnard, E. Thioulouse, J. Jaubert, J.-J. Boffa, J.-P. Haymann, L. Baud, D. Bazin, M. Daudon and E. Letavernier, "An animal model of type A cystinuria due to spontaneous mutation in 129S2/SvPasCrl mice", PLoS One 9(7), e102700 (2014). https://doi.org/10.1371/journal.pone. 0102700

85. V. Frochot, D. Bazin, E. Letavernier, Ch. Jouanneau, J.-Ph. Haymann and M. Daudon, "Nephrotoxicity induced by drugs: the case of foscarnet and atazanavir - a SEM and $\mu F T$-IR investigation",
C.R. Chim. 19(11-12), 1565 (2016). https://doi. org/10.1016/j.crci.2016.08.007

86. Y. Luque, K. Louis, C. Jouanneau, S. Placier, E. Esteve, D. Bazin, E. Rondeau, E. Letavernier, A. Wolfromm, C. Gosset, A. Boueilh, M. Burbach, P. Frère, M.-C. Verpont, S. Vandermeersch, D. Langui, M. Daudon, V. Frochot and L. Mesnard, "Vancomycin-associated cast nephropathy", J. Am. Soc. Nephrol. 28(6), 1723 (2017). https://doi. org/10.1681/ASN.2016080867

87. A.-L. Faucon, M. Daudon, V. Frochot, D. Bazin, B. Terris and V. Caudwell, "Delayed ileal perforation from sodium polystyrene sulfonate", Kidney Int. 93(5), 1251 (2018). https://doi.org/10.1016/j. kint.2017.10.014

88. H. Colboc, D. Bazin, P. Moguelet, V. Frochot, E. Letavernier, C. Jouanneau, J.F. Bernaudin and M. Daudon, "Detection of crystalline $\mathrm{SiO}_{2}$ and $\mathrm{Ca}$ carbonate deposits in granulomatous areas of skin sarcoidosis by $\mu F T-I R$ and FE-SEM coupled with EDX spectroscopy analysis", C.R. Chim. 19, 1631 (2016). https://doi.org/10.1016/j.crci.2016.05.007

89. H. Colboc, P. Moguelet, D. Bazin, C. Bachmeyer, V. Frochot, R. Weil, E. Letavernier, C. Jouanneau, M. Daudon and J.F. Bernaudin, "Physicochemical characterization of inorganic deposits associated with granulomas in cutaneous sarcoidosis", J. Eur. Acad. Dermatol. Venereol. 33(1), 198 (2019). https://doi. org/10.1111/jdv.15167

90. A. Dessombz, B. Kirakoya, G. Coulibaly, R.W. Ouedraogo, L. Picaut, R. Weil, D. Bazin and M. Daudon, "High prevalence of opaline silica in urinary stones from Burkina Faso", Urology 86(6), 1090 (2015). https://doi.org/10.1016/j.urology.2015.06.068

91. A. Dessombz, G. Coulibaly, B. Kirakoya, R.W. Ouedraogo, A. Lengani, S. Rouzière, R. Weil, L. Picaut, Ch. Bonhomme, F. Babonneau, D. Bazin and M. Daudon, "Structural elucidation of silica present in kidney stones coming from BurkinaFaso", C.R. Chim. 19(11-12), 1573 (2016). https://doi. org/10.1016/j.crci.2016.06.012

92. F. Brunet-Possenti, L. Deschamps, H. Colboc, A. Somogyi, K. Medjoubi, D. Bazin and V. Descamps, "Detection of titanium nanoparticles in the hair shafts of a patient with frontal fibrosing alopecia", J. Eur. Acad. Dermatol. Venereol. 32(12), e442 (2018). https://doi.org/10.1111/jdv.14967 
93. L. Estepa and M. Daudon, "Contribution of Fourier transform infrared spectroscopy to the identification of urinary stones and kidney crystal deposits", Biospectroscopy 3(5), 347 (1997). https://doi. org/10.1002/(SICI)1520-6343(1997)3:5<347::AIDBSPY3>3.0.CO;2-\%23

94. S. Rouzière, D. Bazin and M. Daudon, "In-lab X-ray fluorescence and diffraction techniques for pathological calcifications", C.R. Chim. 19(11-12), 1404 (2016). https://doi.org/10.1016/j.crci.2015.05.013

95. P.M. Bertsch and D.B. Hunter, "Applications of synchrotron-based X-ray microprobes", Chem. Rev. 101(6), 1809 (2001). https://doi.org/10.1021/ cr990070s

96. S. Li, W. Zhang and L. Wang, "Direct nanoscale imaging of calcium oxalate crystallization on brushite reveals the mechanisms underlying stone formation", Cryst. Growth Des. 15(6), 3038 (2015). https://doi. org/10.1021/acs.cgd.5b00482

97. C. Verrier, D. Bazin, L. Huguet, O. Stéphan, A. Gloter, M.-C. Verpont, V. Frochot, J.-P. Haymann, I. Brocheriou, O. Traxer, M. Daudon and E. Letavernier, "Topography, composition and structure of incipient Randall's plaque at the nanoscale level", J. Urol. 196(5), 1566 (2016). https://doi.org/10.1016/j. juro.2016.04.086

98. D. Bazin, E. Letavernier, J.-P. Haymann, P. Méria and M. Daudon, "La place de la physicochimie en urologie et en néphrologie: le bilan de 10ans de collaboration entre physiciens, chimistes et praticiens hospitaliers", Prog. Urol. 26(11-12), 608 (2016). https://doi. org/10.1016/j.purol.2016.08.019

99. G. Laffite, C. Leroy, C. Bonhomme, L. BonhommeCoury, E. Letavernier, M. Daudon, V. Frochot, J.P. Haymann, S. Rouzière, I.T. Lucas, D. Bazin, F. Babonneau and A. Abou-Hassan, "Calcium oxalate precipitation by diffusion using laminar microfluidics: toward a biomimetic model of pathological microcalcifications", Lab Chip 16(7), 1157 (2016). https://doi. org/10.1039/C6LC00197A

100. H. Colas, L. Bonhomme-Coury, C. Coelho, F. Tielens, F. Babonneau, Ch. Gervais, D. Bazin, D. Laurencin, M.E. Smith, J.V. Hanna, M. Daudon and $\mathrm{Ch}$. Bonhomme, "Whewellite, $\mathrm{CaC}_{2} \mathrm{O}_{4} \cdot \mathrm{H}_{2} \mathrm{O}$ : A combined NMR and crystallography approach", CrystEngComm 15, 8840 (2013). https://doi. org/10.1039/c3ce41201f
101. S. Kaščáková, C.M. Kewish, S. Rouzière, F. Schmitt, R. Sobesky, J. Poupon, C. Sandt, B. Francou, A. Somogyi, D. Samuel, E. Jacquemin, A. DubartKupperschmitt, T.H. Nguyen, D. Bazin, J.-C. DuclosVallée, C. Guettier and F. Le Naour, "Rapid and reliable diagnosis of Wilson disease using X-ray fluorescence", J. Pathol. Clin. Res. 2(3), 175 (2016). https://doi.org/10.1002/cjp2.48

102. S. Reguer, C. Mocuta, D. Thiaudière, M. Daudon and D. Bazin, "Combination of X-ray synchrotron radiation techniques combination to gather information for the clinician", C.R. Chim. 19(11-12), 1424 (2016). https://doi.org/10.1016/j.crci.2015.03.012

103. E. Esteve, S. Reguer, C. Boissiere, C. Chanéac, G. Lugo, C. Jouanneau, C. Mocuta, D. Thiaudière, N. Leclercq, B. Leyh, J.F. Greisch, J. Berthault, M. Daudon, P. Ronco and D. Bazin, "Flyscan opportunities in medicine: the case of quantum rattle based on gold quantum dots", J. Synchrotron Radiat. 24(Pt 5), 991 (2017). https://doi.org/10.1107/ S1600577517009572

104. J. Rode, D. Bazin, A. Dessombz, Y. Benzerara, E. Letavernier, N. Tabibzadeh, A. Hoznek, M. Tligui, O. Traxer, M. Daudon and J.-P. Haymann, "Daily green tea infusions in hypercalciuric renal stone patients: no evidence for increased stone risk factors or oxalate-dependent stones", Nutrients 11(2), 256 (2019). https://doi.org/10.3390/nu11020256

105. J. Tonannavar, G. Deshpande, J. Yenagi, S.B. Patil, N.A. Patil and B.G. Mulimani, "Identification of mineral compositions in some renal calculi by FT Raman and IR spectral analysis", 154, 20 (2016). https://doi. org/10.1016/j.saa.2015.10.003

106. M. Daudon, M.F. Protat, R.J. Réveillaud and $H$. Jaeschke-Boyer, "Infrared spectrometry and Raman microprobe in the analysis of urinary calculi", Kidney Int. 23(6), 842 (1983). https://doi.org/10.1038/ ki.1983.104

107. K. Sekkoum, A. Cheriti, S. Taleb and N. Belboukhari, "FT-IR spectroscopic study of human urinary stones from El Bayadh district (Algeria)", Arab. J. Chem. 9(3), 330 (2016). https://doi.org/10.1016/j.arabjc.2011.10.010

108. A. Dazzi and C.B. Prater, "AFM-IR: technology and applications in nanoscale infrared spectroscopy and chemical imaging", Chem. Rev. 117(7), 5146 (2017). https://doi.org/10.1021/acs.chemrev.6b00448 
109. L. Henry, N. Delsuc, C. Laugel, F. Lambert, C. Sandt, S. Hostachy, A.-S. Bernard, H.C. Bertrand, L. Grimaud, A. Baillet-Guffroy, C. Policar and C. Policar, "Labeling of hyaluronic acids with a rheniumtricarbonyl tag and percutaneous penetration studied by multimodal imaging", Bioconjug. Chem. 29(4), 987 (2018). https://doi.org/10.1021/acs. bioconjchem.7b00825

110. F. Le Naour, L. Gadea, M. Danulot, I. Yousef, E. Vibert, M. Wavelet, S. Kaščáková, D. Castaing, D. Samuel, P. Dumas and C. Guettier, "Quantitative assessment of liver steatosis on tissue section using infrared spectroscopy", Gastroenterology 148(2), 295 (2015). https://doi.org/10.1053/j.gastro.2014.11.038

111. M. Daudon, C. Marfisi, B. Lacour and C. Bader, "Investigation of urinary crystals by Fourier transform infrared microscopy", Clin. Chem. 37(1), 83 (1991).

112. M. Daudon, J.-C. Doré, P. Jungers and B. Lacour, "Changes in stone composition according to age and gender of patients: a multivariate epidemiological approach", Urol. Res. 32(3), 241 (2004). https://doi. org/10.1007/s00240-004-0421-y

113. A. Dessombz, E. Letavernier, J.-P. Haymann, D. Bazin and M. Daudon, "Calcium phosphate stone morphology can reliably predict distal renal tubular acidosis", J. Urol. 193(5), 1564 (2015). https://doi. org/10.1016/j.juro.2014.12.017

114. M. Daudon, O. Traxer, P. Conort, B. Lacour and P. Jungers, "Type 2 diabetes increases the risk for uric acid stones", J. Am. Soc. Nephrol. 17(7), 2026 (2006). https://doi.org/10.1681/ASN.2006030262

115. X. Carpentier, M. Daudon, O. Traxer, P. Jungers, A. Mazouyes, G. Matzen, E. Véron and D. Bazin, "Relationships between carbonation rate of carbapatite and morphologic characteristics of calcium phosphate stones and etiology", Urology 73(5), 968 (2009). https://doi.org/10.1016/j.urology.2008.12.049

116. D. Bazin, G. André, R. Weil, G. Matzen, V. Emmanuel, X. Carpentier and M. Daudon, "Absence of bacterial imprints on struvite-containing kidney stones: a structural investigation at the mesoscopic and atomic scale", Urology 79(4), 786 (2012). https:// doi.org/10.1016/j.urology.2011.08.054

117. L. Estepa-Maurice, C. Hennequin, C. Marfisi, C. Bader, B. Lacour and M. Daudon, "Fourier transform infrared microscopy identification of crystal deposits in tissues: clinical importance in various pathologies", Am. J. Clin. Pathol. 105(5), 576 (1996). https://doi. org/10.1093/ajcp/105.5.576

118. D. Bazin, Ch. Jouanneau, S. Bertazzo, Ch. Sandt, A. Dessombz, M. Réfrégiers, P. Dumas, J. Frederick, J.-Ph. Haymann, E. Letavernier, P. Ronco and M. Daudon, "Combining FE-SEM, deep UV fluorescence, Raman, SR-FT-IR spectroscopy in the study of crystal-containing kidney biopsies", C.R. Chim. 19, 1439 (2016). https://doi.org/10.1016/j. crci.2015.03.001

119. D. Bazin, E. Letavernier, J.-Ph. Haymann, F. Tielens, A. Kellum and M. Daudon, "Shedding light on the morphology of calcium oxalate monohydrate crystallites present in kidney biopsies in the case of hyperoxaluria", C.R. Chim. 19(11-12), 1548 (2016). https://doi.org/10.1016/j.crci.2016.02.004

120. E. Esteve, C. Jouanneau, E. Letavernier, P. Ronco, M. Daudon, D. Bazin and M. Réfrégiers, "Utilisation de la microspectroscopie UV pour la détection et la localisation de l'oxalate de calcium dans le rein", Nephrol. Ther. 11(5), 279 (2015). https://doi. org/10.1016/j.nephro.2015.07.051

121. V.W. Petit, M. Réfrégiers, C. Guettier, F. Jamme, K. Sebanayakam, A. Brunelle, O. Laprévote, P. Dumas and F. Le Naour, "Multimodal spectroscopy combining time-of-flight-secondary ion mass spectrometry, synchrotron-FT-IR, and synchrotron-UV microspectroscopies on the same tissue section", Anal. Chem. 82(9), 3963 (2010). https://doi.org/10.1021/ ac100581y

122. D. Bazin, P. Chevallier, G. Matzen, P. Jungers and M. Daudon, "Heavy elements in urinary stones", Urol. Res. 35(4), 179 (2007). https://doi.org/10.1007/ s00240-007-0099-z

123. B. Hannache, A. Boutefnouchet, D. Bazin, E. Foy and M. Daudon, "Le role des éléments traces dans la pathogenèse des calculs rénaux", Prog. Urol. 25, 22 (2015). https://doi.org/10.1016/j.purol.2014.09.038

124. Y. Yen, B. Cheng, C. Chan, C. Lin and H. Chen, "Heavy metal components in blood and urinary stones of urolithiasis patients", Biol. Trace Elem. Res. 185(2), 266 (2018). https://doi.org/10.1007/s12011018-1253-x

125. R.K.B. Devi, H.N. Sarma and S. Kumar, "Trace and major elements in anti-utolithiatic medicinal plants", Int. J. Pharm. Sci. Res. 7, 1640 (2016). https://doi. org/10.13040/IJPSR.0975-8232 
126. D.R. Scott, C. Kendall, N. Stone and K. Rogers, "Locating microcalcifications in breast histopathology sections using micro CT and XRF mapping", Anal. Methods 6(12), 3962 (2014). https://doi.org/10.1039/ C3AY42158A

127. G. Schlieper, A. Aretz, S.C. Verberckmoes, T. Krüger, G.J. Behets, R. Ghadimi, T.E. Weirich, D. Rohrmann, S. Langer, J.H. Tordoir, K. Amann, R. Westenfeld, V.M. Brandenburg, P.C. D'Haese, J. Mayer, M. Ketteler, M.D. McKee and J. Floege, "Ultrastructural analysis of vascular calcifications in uremia", J. Am. Soc. Nephrol. 21(4), 689 (2010). https://doi.org/10.1681/ASN.2009080829

128. A. Dessombz, C. Nguyen, H.-K. Ea, S. Rouzière, E. Foy, D. Hannouche, S. Réguer, F.-E. Picca, D. Thiaudière, F. Lioté, M. Daudon and D. Bazin, "Combining $\mu X$-ray fluorescence, $\mu$ XANES and $\mu$ XRD to shed light on $\mathrm{Zn}^{2+}$ cations in cartilage and meniscus calcifications", J. Trace Elem. Med. Biol. 27(4), 326 (2013). https://doi.org/10.1016/j.jtemb.2013.02.001

129. F. Meirer, B. Pemmer, G. Pepponi, N. Zoeger, P. Wobrauschek, S. Sprio, A. Tampieri, J. Goettlicher, R. Steininger, S. Mangold, P. Roschger, A. Berzlanovich, J.G. Hofstaetter and C. Streli, "Assessment of chemical species of lead accumulated in tidemarks of human articular cartilage by X-ray absorption near-edge structure analysis", J. Synchrotron Radiat. 18(Pt 2), 238 (2011). https://doi.org/10.1107/ S0909049510052040

130. B. Rosenberg, L. VanCamp, J.E. Trosko and V.H. Mansour, "Platinum compounds: a new class of potent antitumour agents", Nature 222(5191), 385 (1969). https://doi.org/10.1038/222385aO

131. E. Esteve, D. Bazin, C. Jouanneau, S. Rouzière, A. Bataille, A. Kellum, K. Provost, Ch. Mocuta, S. Reguer, P. Ronco, J. Rehr, J.-Ph. Haymann, E. Letavernier and A. Hertig, "How assess the role of Pt and Zn in the nephrotoxicity of Pt anti cancer drugs? An investigation combining $\mu \mathrm{XRF}$ and statistical analysis. Part I: on mice", C.R. Chim. 19(11-12), 1580 (2016). https://doi.org/10.1016/j. crci.2016.03.014

132. E. Esteve, D. Bazin, C. Jouanneau, S. Rouzière, A. Bataille, A. Kellum, K. Provost, Ch. Mocuta, S. Reguer, P. Ronco, J. Rehr, J.-Ph. Haymann, E. Letavernier and A. Hertig, "How to assess the role of Pt and $\mathrm{Zn}$ in the nephrotoxicity of Pt anti cancer drugs? An investigation combining $\mu \mathrm{XRF}$ and statis- tical analysis. Part II: clinical application", C.R. Chim. 19(11-12), 1586 (2016). https://doi.org/10.1016/j. crci.2016.02.015

133. D. Bazin, D. Sayers, J.J. Rehr and C. Mottet, "Numerical simulation of the Pt $\mathrm{L}_{|| \mid}$edge white line relative to nanometer scale clusters", J. Phys. Chem. 101(27), 5332 (1997). https://doi.org/10.1021/ jp963949+

134. D. Bazin, D. Sayers and J. Rehr, "Comparison between $\mathrm{X}$-ray absorption spectroscopy, anomalous wide angle $X$-ray scattering, anomalous small angle $X$-ray scattering, and diffraction anomalous fine structure techniques applied to nanometer-scale metallic clusters", J. Phys. Chem. B 101(51), 11040 (1997). https://doi.org/10.1021/jp9721311

135. D. Bazin and J. Rehr, "Limits and advantages of x-ray absorption near edge structure for nanometer scale metallic clusters", J. Phys. Chem. B 107(45), 12398 (2003). https://doi.org/10.1021/jp0223051

136. I. Nicolis, E. Curis, P. Deschamps and S. Bénazeth, "X-ray absorption spectroscopy of low-molar-mass metallic complexes in pharmacy", J. Synchrotron Radiat. 10(Pt 1), 96 (2003). https://doi.org/10.1107/ S0909049502017259

137. Y. Min, J.M. Caster, M.J. Eblan and A.Z. Wang, "Clinical translation of nanomedicine", Chem. Rev. 115(19), 11147 (2015). https://doi.org/10.1021/acs. chemrev.5b00116

138. C.M. Weekley, J.B. Aitken, L. Finney, S. Vogt, P.K. Witting and H.H. Harris, "Selenium metabolism in cancer cells: the combined application of XAS and XFM techniques to the problem of selenium speciation in biological systems", Nutrients 5(5), 1734 (2013). https://doi.org/10.3390/nu5051734

139. E.-C. Ahlgren, M. Fekry, M. Wiemann, C.A. Söderberg, K. Bernfur, O. Gakh, M. Rasmussen, P. Højrup, C. Emanuelsson, G. Isaya and S. Al-Karadaghi, "Iron-induced oligomerization of human FXN81-210 and bacterial CyaY frataxin and the effect of iron chelators", PLoS One 12(12), e0188937 (2017). https://doi.org/10.1371/journal. pone.0188937

140. J. Moonen, J. Slot, L. Lefferts, D. Bazin and H. Dexpert, "The influence of polydispersity and inhomogeneity on EXAFS of bimetallic catalysts", Physica B 208, 689 (1995). https://doi. org/10.1016/0921-4526(94)00791-S 
141. A. Randall, "An hypothesis for the origin of renal calculus", N. Engl. J. Med. 214(6), 234 (1936). https:// doi.org/10.1056/NEJM193602062140603

142. T. Alelign and B. Petros, "Kidney stone disease: An update on current concepts", Adv. Urol. 2018, 3068365 (2018). https://doi. org/10.1155/2018/3068365

143. M. Daudon, D. Bazin and E. Letavernier, "Randall's plaque as the origin of calcium oxalate kidney stones", Urolithiasis 43(S1), 5 (2015). https://doi. org/10.1007/s00240-014-0703-y

144. I. Sethmann, G. Wendt-Nordahl, T. Knoll, F. Enzmann, L. Simon and H.-J. Kleebe,

"Microstructures of Randall's plaques and their interfaces with calcium oxalate monohydrate kidney stones reflect underlying mineral precipitation mechanisms", Urolithiasis 45(3), 235 (2017). https:// doi.org/10.1007/s00240-016-0925-2

145. J.C. Williams and J.A. McAteer, "Retention and growth of urinary stones: insights from imaging", J. Nephrol. 26(1), 25 (2013). https://doi.org/10.5301/ jn. 5000208

146. K. Bouchireb, O. Boyer, C. Pietrement, $H$. Nivet, $H$. Martelli, O. Dunand, F. Nobili, G.L. Sylvie, P. Niaudet, R. Salomon and M. Daudon, "Papillary stones with Randall's plaques in children: clinicobiological features and outcome", Nephrol. Dial. Transplant. 27(4), 1529 (2012). https://doi.org/10.1093/ndt/gfr439

147. X. Carpentier, D. Bazin, P. Junger, S. Reguer, D. Thiaudière and M. Daudon, "The pathogenesis of Randall's plaque?: A papilla cartography through an ex vivo study based on XANES spectroscopy", J. Synchrotron Radiat. 17, 374 (2010). https://doi. org/10.1107/S0909049510003791

148. E. Letavernier, C. Verrier, F. Goussard, J. Perez, L. Huguet, J.-P. Haymann, L. Baud, D. Bazin and M. Daudon, "Calcium and vitamin D have a synergistic role in a rat model of kidney stone disease", Kidney Int. 90(4), 809 (2016). https://doi.org/10.1016/j. kint.2016.05.027

149. M. Daudon, "[Vitamin D, Randall plaques and nephrolithiasis: are they related?]", Arch. Pediatr. 20(4), 336 (2013). https://doi.org/10.1016/j. arcped.2012.12.028

150. A. Le Bail, "Monte Carlo indexing with McMaille", Powder Diffr. 19(3), 249 (2004). https://doi. org/10.1154/1.1763152
151. A. Le Bail, D. Bazin, M. Daudon, A. Brochot, V. Robbez-Masson and V. Maisonneuve, "Racemic calcium tartrate tetrahydrate [form (II)] in rat urinary stones", Acta Crystallogr. B 65(Pt 3), 350 (2009). https://doi.org/10.1107/S0108768109013688

152. A. Le Bail, M. Daudon and D. Bazin, "A new compound in kidney stones? Powder X-ray diffraction study of calcium glycinate trihydrate", Acta Crystallogr. C 69(Pt 7), 734 (2013). https://doi. org/10.1107/S0108270113015709

153. D. Bazin, M. Daudon, E. Elkaim, A. Le Bail and L. Smrcok, "Ab initio structure determination of kidney stone potassium quadriurate from synchrotron powder diffraction data, a 150 year problem solved", C.R. Chim. 19(11-12), 1535 (2016). https://doi. org/10.1016/j.crci.2015.02.003

154. M. Daudon, D. Bazin, G. André, P. Jungers, A. Cousson, P. Chevallier, E. Véron and G. Matzen, "Examination of whewellite kidney stones by scanning electron microscopy and powder neutron diffraction techniques", J. Appl. Cryst. 42, 109 (2009). https://doi.org/10.1016/j.crci.2015.04.006

155. M. Daudon, E. Letavernier, R. Weil, E. Véron, G. Matzen, G. André and D. Bazin, "Type 2 diabetes and uric acid stones: A powder neutron diffraction investigation", C.R. Chim. 19(11-12), 1527 (2016). https://doi.org/10.1016/j.crci.2015.04.006

156. F. Damay, D. Bazin, M. Daudon and G. André, "Neutron diffraction as a probe for the characterization of biological entities", C.R. Chim. 19(11-12), 1432 (2016). https://doi.org/10.1016/j. crci.2015.01.011

157. S.J. Zinkle, G.E. Ice, M.K. Miller, S.J. Pennycook and X.-L. Wang, "Advances in microstructural characterization", J. Nucl. Mater. 386-388, 8 (2009). https:// doi.org/10.1016/j.jnucmat.2008.12.302

158. L. Louvet, D. Bazin, J. Büchel, S. Steppan, J. Passlick-Deetjen and Z.A. Massy, "Characterisation of calcium phosphate crystals on calcified cultured cells and potential role of magnesium", PLoS One 10, e0115342 (2015). https://doi.org/10.1371/journal. pone.0115342

159. F. Preitner, A. Laverriere, S. Metref, A. Da Costa, C. Roger, S. Rotman, D. Bazin, M. Daudon, Ch. Sandt, A. Dessombz and B. Thorens, "Controlled hyperuricemia in liver-specific Glut9 knockout mice as a model of acute renal failure", Am. J. 
Physiol. Renal Physiol. 305, F786 (2013). https://doi. org/10.1152/ajprenal.00083.2013

160. E. Letavernier, G. Kauffenstein, L. Huguet, N. Navasiolava, E. Bouderlique, E. Tang, L. Delaitre, D. Bazin, M. de Frutos, C. Gay, J. Perez, M.C. Verpont, J.-Ph. Haymann, V. Pomozi, J. Zoll, O. Le Saux, M. Daudon, G. Leftheriotis and L. Martin, "ABCC6 transporter deficiency promotes development of Randall's plaque and kidney stones in mice and humans", J. Am. Soc. Nephrol. 29, 2337 (2018). https://doi.org/10.1681/ASN.2017101148

161. H. Bilbault, J. Perez, L. Huguet, S. Vandermeersch, S. Placier, N. Tabibzadeh, V. Frochot, E. Letavernier, D. Bazin, M. Daudon and J.-P. Haymann, "Urothelium proliferation is a trigger for renal crystal deposits in a murine lithogenesis model", Sci. Rep. 8(1), 16319 (2018). https://doi.org/10.1038/s41598018-34734-8
162. D. Bazin, C. Mottet, G. Treglia and J. Lynch, "New trends in heterogeneous catalysis processes on metallic clusters from synchrotron radiation and theoretical studies", Appl. Surf. Sci. 164, 140 (2000). https://doi.org/10.1016/S0169-4332(00)00346-9

163. D. Bazin and F. Tielens, "Operando characterization of nanospinels: relationship with catalytic activity", Appl. Catal. 504, 631 (2015). https://doi. org/10.1016/j.apcata.2015.01.049

164. F. Tielens and D. Bazin, "On the way of understanding the behavior of nanometer scale metallic particles towards adsorption of $\mathrm{CO}$ and $\mathrm{NO}$ molecules", C.R. Chim. 21(3-4), 174 (2018). https:// doi.org/10.1016/j.crci.2017.07.007

165. I.C. Oğuz, H. Guesmi, D. Bazin and F. Tielens, "Predicting the activity of nano-transition-metal DeNox catalysts", J. Phys. Chem. C 123(33), 20314 (2019). https://doi.org/10.1021/acs.jpcc.9b04796 